\title{
Inhibition of Casein Kinase 2 induces Cell Death in Chronic Myelogenous \\ Leukemia Cells with Different Mechanisms of Resistance to Tyrosine
}

\section{Kinase Inhibitors}

Ondřej Mitrovskýl, Denisa Myslivcovál, Tereza Macháčková-Lopotovál, Adam Obr ${ }^{1}$, Kamila

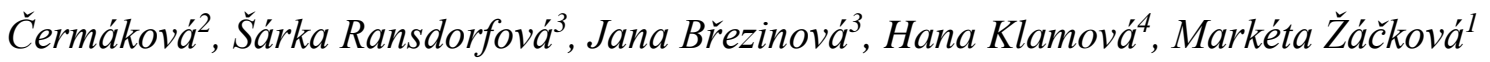

${ }^{1}$ Dept. of Proteomics, Institute of Hematology and Blood Transfusion, U Nemocnice 2094/1, 12800 Prague 2

${ }^{2}$ Laboratory of PCR Diagnostics of Leukemias, Institute of Hematology and Blood Transfusion, U Nemocnice 2094/1, 12800 Prague 2

${ }^{3}$ Dept. of Cytogenetics, Institute of Hematology and Blood Transfusion, U Nemocnice 2094/1, 12800 Prague 2

${ }^{4}$ Clinical Division, Institute of Hematology and Blood Transfusion, U Nemocnice 2094/1, 12800 Prague 2 


\section{$\underline{\text { Abstract }}$}

Chronic myelogenous leukemia (CML) is a myeloproliferative disease characterized by the presence of a BCR-ABL oncogene. Despite the high performance of treatment with tyrosine kinase inhibitors (TKI), about $30 \%$ of patients develop resistance to therapy. To improve the outcome of CML therapy, the identification of new targets of treatment is needed. Here, we explored the Casein Kinase 2 (CK2) as a potential target for CML therapy. Previously, we detected increased phosphorylation of HSP90 $\beta$ Serine 226 in patients non-responding to TKIs imatinib and dasatinib. This site is known to be phosphorylated among others by CK2, which was also previously linked to CML resistance to imatinib. In the present work, we established six novel imatinib- and dasatinib-resistant CML cell lines and detected increased CK2 activation in all these resistant cells. A CK2 inhibitor, CX-4945, induced cell death of CML cells in both parental and resistant cell lines. In some cases, CK2 inhibition also potentiated the effects of TKI on cell metabolic activity. No effects of CK2 inhibition were observed in normal mononuclear blood cells from healthy donors and BCR-ABL negative HL60 cell line. Our data indicate that CK2 kinase supports CML cell viability even in cells with different mechanisms of resistance to TKI, and thus represents a potential target for treatment. 


\section{Introduction}

Chronic myeloid leukemia (CML) is a myeloproliferative disease characterized by the presence of Philadelphia translocation $\mathrm{t}(9 ; 22)(\mathrm{q} 34 ; \mathrm{q} 11)$ giving rise to a fusion gene, Bcr-Abl. The gene product is a constitutively active kinase, BCR-ABL, the main driver of CML ${ }^{1}$. Imatinib, a selective BCR-ABL inhibitor, has been introduced into clinical practice in 2001 and represents a breakthrough in CML therapy ${ }^{2-4}$. Nevertheless, about one-third of patients develop resistance or intolerance to the drug. To address this issue, second-generation tyrosine kinase inhibitors (TKIs) — like dasatinib, nilotinib, and ponatinib — were developed, and are effective against most imatinib-resistant cases of CML.

However, patients treated with advanced generations of TKIs also have a high risk of resistance development to the new drugs ${ }^{5-8}$. Therefore, other therapeutic approaches targeting resistant CML cells are explored. At present, the research in this area focuses on strategies to target pathways not induced by BCR-ABL, including those, which are currently considered as non-oncogenic ${ }^{9-11}$.

Casein kinase 2 (CK2) is a ubiquitously expressed serine/threonine (S/T) kinase. In the cell, it is usually present as a tetrameric complex of two catalytic $\left(\alpha, \alpha^{\prime}\right)$ and two regulatory $(\beta)$ subunits. Although it was previously labeled as constitutively active, several reports now suggest many possible pathways of $\mathrm{CK} 2$ regulation, e.g. via protein interactions, differential phosphorylation, and interactions with other regulatory elements ${ }^{12}$. CK2 is considered as one of the most pleiotropic protein kinases and has a net pro-survival, anti-apoptotic role ${ }^{13-17}$. Its expression is increased in cancer cells ${ }^{18-20}$, and its signaling feeds the usual cancer-related pathways, even reaching the point where cancer cells become CK2-dependent ${ }^{21,22}$. Furthermore, CK2 has also been associated with multi-drug resistance to chemotherapy ${ }^{23-25}$. This all shows CK2 as an important player in cancer pathogenesis, and since some highly 
specific inhibitors are available, it also represents a possible target for treatment ${ }^{12}$. An orally available compound Silmitasertib (CX-4945) is currently evaluated in clinical trials for several cancer types ${ }^{26,27}$, but so far has not been tested for CML treatment ${ }^{28}$.

We used protein-antibody arrays to find proteins differentially expressed and/or phosphorylated in samples of patients divided into groups according to their therapy response (as characterized by ELN ${ }^{29}$ ), and healthy donors. Among others, we detected increased phosphorylation of HSP90 $\beta$ on Ser226 in imatinib- and dasatinib- resistant patients. Phosphorylation of this site was previously identified as CK2-dependent ${ }^{30,31}$. As CK2 is associated with resistance to imatinib ${ }^{32-34}$, we further explored the role of CK2 in the resistance to both imatinib and dasatinib. In TKI-resistant cells, CK2 expression was increased, and all the resistants were also highly sensitive to CK2 inhibition. Additionally, our preliminary data from patients non-responding to the therapy showed corresponding effects of CK2 inhibition on cell viability.

\section{$\underline{\text { Results }}$}

\section{Phosphorylation of HSP90ß S226, a CK2-target, is increased in patients non-responding to} TKI

Using protein-antibody arrays, we analyzed 14 samples of total leukocytes obtained from patients at different stages of CML and with different responses to the standard therapy (as defined by the ELN). The patient characteristics are provided in Table 1A. We found several proteins to be differentially expressed and/or phosphorylated in patient samples compared to healthy donors. Besides the usual suspects, such as BCR-ABL and SFK (data not shown), we found changes at phosphorylation sites of the heat-shock proteins HSP90 and HSP27 (Figure 1, Supplementary Figure S1). Phosphorylation of most of these sites did not correlate with the 
bioRxiv preprint doi: https://doi org/10.1101/2021.06 28 450156; this version posted June 28,2021 . The copyright holder for this preprint (which was not certified by peer review) is the author/funder, who has granted bioRxiv a license to display the preprint in perpetuity. It is made available under aCC-BY-NC-ND 4.0 International license.

disease outcome, as shown in Supplementary Figure S1. However, we identified a systematic increase of HSP90 3226 phosphorylation in samples from patients non-responding to therapy, or relapsed, compared to healthy donors (Figure 1A). Additionally, for two of the patients, we performed the screen at the time of diagnosis and subsequently 10 and 11 months after treatment initiation (Figure 1B). The ratio of HSP90 $\beta$ phosphorylated on S226 to total HSP90 $\beta$ was markedly higher in the non-responding patient. Characteristics of those two patients are given in Table $1 \mathrm{~B}$.
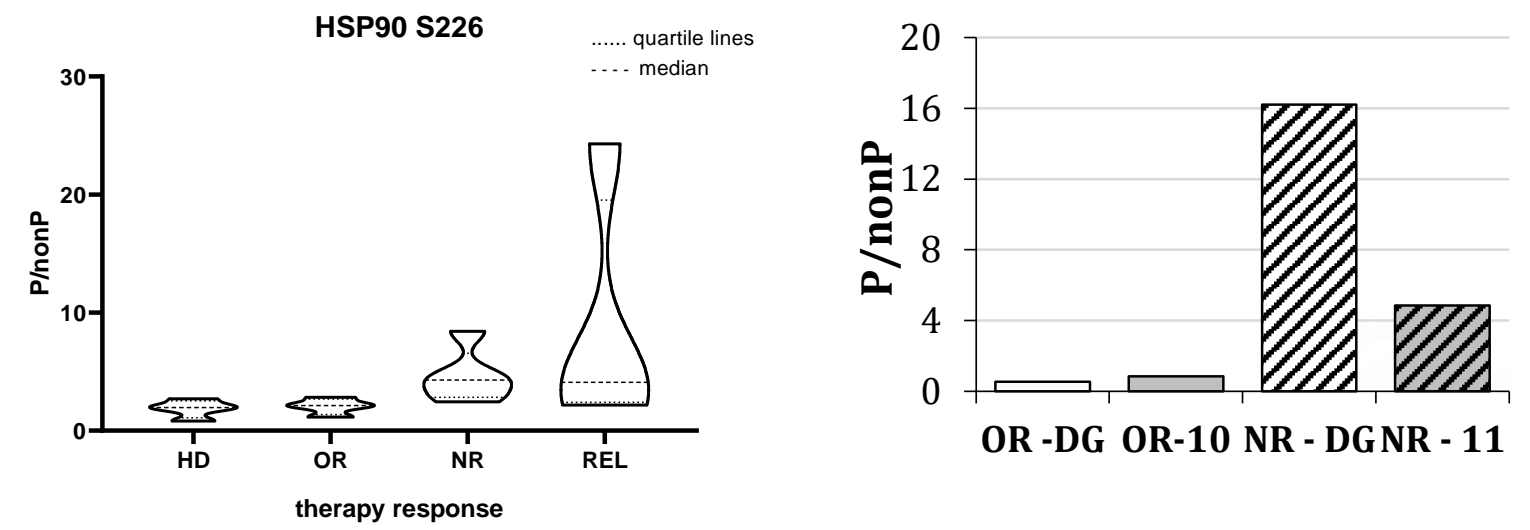

\section{Figure 1 | HSP90 Serine 226 phosphorylation in CML patients with different response to therapy}

(A) Protein-antibody array analyses of 14 samples of patients with different response to therapy. The values for the ratio of HSP90 amounts with phosphorylated and unphosphorylated Ser226 are given in violin plots as the medians and quartiles and the distribution of the values in each group: HD Healthy Donors, OR - Optimal Response, NR — non-responding patients, REL — relapsed patients. Detailed patients characteristics are provided in Table 1.

(B) Changes in pS226 / non-phosphorylated S226 ratios in one patient with an optimal response (OR) and one without response (NR) to therapy. DG — levels at the time of diagnosis, 10 (11) levels at 10 or 11 months after the start of the treatment. 
A)

\begin{tabular}{|c|c|c|c|c|c|c|c|c|c|c|}
\hline \multicolumn{11}{|c|}{ Basic characteristics of patients } \\
\hline \multirow{2}{*}{$\begin{array}{c}\text { group } \\
\text { ID }\end{array}$} & \multirow[b]{2}{*}{ (n) } & \multirow[b]{2}{*}{$\mathrm{F} / \mathrm{M}$} & \multicolumn{8}{|c|}{ at analysis } \\
\hline & & & $\begin{array}{l}\text { months } \\
\text { from DG }\end{array}$ & $\begin{array}{l}\text { therapy } \\
\text { IM/D/N }\end{array}$ & $\begin{array}{c}\text { BCR-ABL } \\
(\%)\end{array}$ & $\begin{array}{c}\text { WBC } \\
10^{\wedge} 9 / L \\
\end{array}$ & $\begin{array}{c}\text { PLT } \\
10^{\wedge} 9 / \mathrm{L} \\
\end{array}$ & $\begin{array}{c}\text { blasts } \\
(\%)\end{array}$ & $\begin{array}{c}\text { mutation } \\
\text { (n) }\end{array}$ & $\begin{array}{c}\text { aberations } \\
\text { (n) }\end{array}$ \\
\hline OR & 4 & $4 / 0$ & $\begin{array}{c}70,3 \\
(12-141)\end{array}$ & $3 / 0 / 1$ & $\begin{array}{c}\mathbf{0} \\
(0-0,001)\end{array}$ & $\begin{array}{c}\mathbf{5 , 3 5} \\
(3,98-14,4)\end{array}$ & $\begin{array}{c}202 \\
(170-268)\end{array}$ & 0 & 0 & 0 \\
\hline NR & 5 & $3 / 2$ & $\begin{array}{c}\mathbf{5 2 , 9} \\
(12-141)\end{array}$ & $3 / 2 / 0$ & $\begin{array}{c}13 \\
(4,7-33)\end{array}$ & $\begin{array}{c}4,3 \\
(3,26-7,79)\end{array}$ & $\begin{array}{c}198 \\
(95-212)\end{array}$ & 0 & 1 & 1 \\
\hline REL & 5 & $3 / 2$ & $\begin{array}{c}52 \\
(33-164)\end{array}$ & $2 / 2 / 1$ & $\begin{array}{c}57,5 \\
\left(1,1^{*}-109\right)\end{array}$ & $\begin{array}{c}10,88 \\
(3,9-22,05)\end{array}$ & $\begin{array}{c}204 \\
(52-420)\end{array}$ & $\begin{array}{c}0 \\
(0-2,4)\end{array}$ & 2 & 2 \\
\hline HD & 5 & $3 / 2$ & & & & & & & & \\
\hline
\end{tabular}

B)

\begin{tabular}{|c|c|c|c|c|c|c|c|c|}
\hline \multicolumn{9}{|c|}{ Basic characteristics of patients } \\
\hline & \multirow[b]{2}{*}{ Sex } & \multirow{2}{*}{$\begin{array}{c}\text { Age at } \\
\text { DG } \\
\text { (years) }\end{array}$} & \multicolumn{6}{|c|}{ at time of analysis } \\
\hline & & & $\begin{array}{l}\text { Months } \\
\text { from DG }\end{array}$ & $\begin{array}{c}\text { BCR-ABL } \\
(\%)\end{array}$ & $\begin{array}{c}\text { WBC } \\
10^{\wedge 9 / L}\end{array}$ & $\begin{array}{c}\text { PLT } \\
\text { 10^g/L }\end{array}$ & $\begin{array}{c}\text { blasts } \\
\text { (\%) }\end{array}$ & therapy \\
\hline \multirow{2}{*}{ NR } & \multirow{2}{*}{$\mathrm{F}$} & \multirow{2}{*}{49} & 0 & 184 & 66,59 & 454 & 1 & \\
\hline & & & 11 & 4,7 & 5,75 & 178 & 0 & imatinib \\
\hline \multirow{2}{*}{ OR } & \multirow{2}{*}{$\mathrm{F}$} & \multirow{2}{*}{67} & 0 & 52 & 56,11 & 502 & 1 & \\
\hline & & & 10 & 0,001 & 5,91 & 216 & 0 & imatinib \\
\hline
\end{tabular}

Table 1. Characteristics of the patients included in the protein-antibody array analysis

(A) A total of $14 \mathrm{CML}$ patients divided according to their response to therapy: OR - optimal response, $\mathrm{NR}$ - nonresponding, REL — relapsed, HD - healthy donors.

(B) Two patients, one with an optimal response (OR) and one nonresponding (NR) to therapy, analyzed at the time of diagnosis (DG) and 11 months after treatment initiation.

$D G$ - diagnosis, therapy: imatinib/dasatinib/nilotinib, BCR-ABL \% - mRNA level, WBC white blood cell count, PLT - platelet count, blasts - \% of blast cells in total cell count in peripheral blood sample. mutation - mutations in the Bcr-Abl kinase domain, aberations karyotype aberations 


\section{Establishment and characterization of six novel BCR-ABL positive cell lines resistant either to imatinib or dasatinib}

Since the availability of new patient samples is limited, we established six new TKI-resistant cell lines, derived from widely-used CML models JURL-MK1, MOLM-7, and K562. Cells able to grow in media containing clinically achievable concentrations of the respective TKI ( $2 \mu \mathrm{M}$ imatinib, $2 \mathrm{nM}$ dasatinib) are further denoted as "TKI resistant". Cells developed under the selective pressure of imatinib are designated as "IR"; cells developed under the selective pressure of dasatinib are labeled accordingly as "DR". BCR-ABL negative cell lines HL-60 and OCI-AML3 were cultivated under the same conditions as CML cell lines and were used in our experiments as controls. The properties of the new cell lines were characterized as described below.

\section{Cell growth}

Cell growth and viability of the new cell lines were assessed by trypan blue staining after treatment with either $10 \mu \mathrm{M}$ imatinib, or $100 \mathrm{nM}$ dasatinib (Supplementary Figure S2). All the resistant sub-lines demonstrated decreased sensitivity to TKIs, compared to their parental cell lines. Notably, various levels of cross-resistance (i.e. resistance to both TKIs used) were detectable in all the resistant cells. The growth of BCR-ABL negative cells remained unaffected by the presence of TKIs.

\section{$\underline{\text { Sensitivity to TKI }}$}

Table 2 summarizes the EC50 values calculated from the measurement of cell viability after $48 \mathrm{~h}$ TKI treatment. All the resistant sub-lines exhibited lower sensitivity to both TKIs. Similar to the results of cell growth experiments, various levels of cross-resistance were evident in all the sub-lines. This is exemplified by the imatinib-resistant JURL-MK1_IR cells, which were also highly resistant to dasatinib (Figure 2). 
A

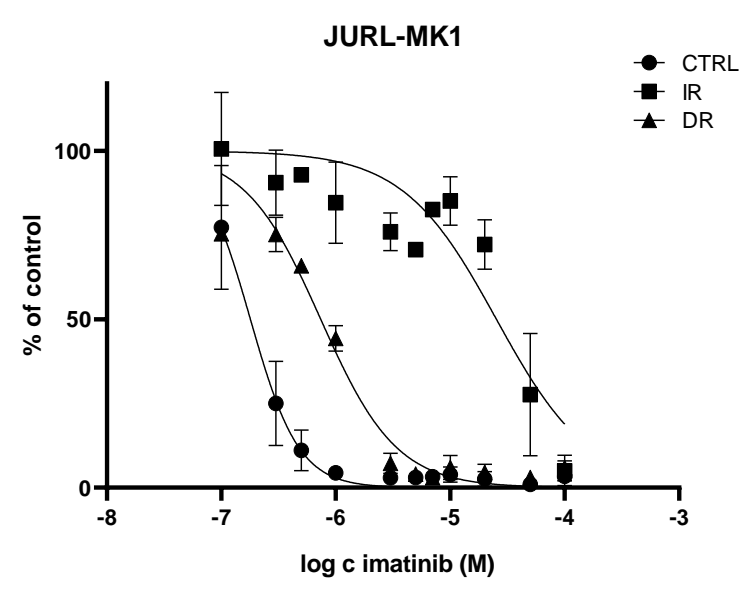

B

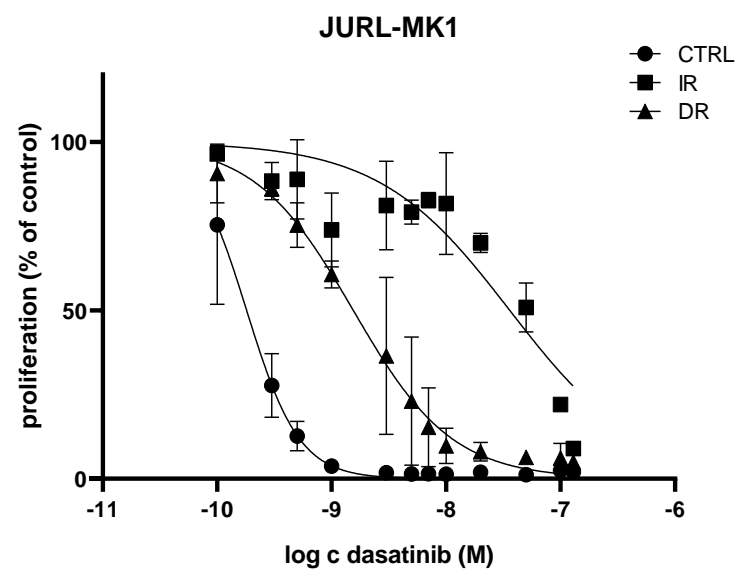

Figure 2 | Dose-response curves for dasatinib and imatinib tested in JURL-MK1 cells and their resistant sub-lines

Representative dose-response curves for imatinib (A) and dasatinib (B) treated cell line JURL-MK1 (ctrl) and its resistant sub-lines (IR - imatinib-resistant, DR - dasatinib-resistant). Imatinib was used in the range $0-100 \mu \mathrm{M}$, dasatinib $0-100 \mathrm{nM}$. The effect of the inhibitor after $48 \mathrm{~h}$ was assessed by proliferation/cell activity changes (AlamarBlue). Graphs are means from 2-3 independent experiments, bars $=$ s.d.

\begin{tabular}{|c|c|c|c|c|c|c|}
\hline & \multicolumn{3}{|c|}{ imatinib $(\mu \mathrm{M})$} & \multicolumn{3}{c|}{ dasatinib (nM) } \\
\cline { 2 - 7 } & $\mathrm{EC50}$ & \multicolumn{2}{|c|}{$\mathrm{Cl}(\mathbf{9 5} \%)$} & $\mathrm{EC50}$ & \multicolumn{2}{c|}{$\mathrm{Cl}(\mathbf{9 5} \%)$} \\
\hline JURL-MK1_K & $\mathbf{0 , 1 8}$ & 0,16 & 0,20 & $\mathbf{0 , 1 6}$ & 0,14 & 0,19 \\
\hline JURL-MK1_IR & $\mathbf{2 5 , 3}$ & 17,2 & 38,1 & $\mathbf{3 5 , 7}$ & 23,5 & 63,3 \\
\hline JURL-MK1_DR & $\mathbf{0 , 7}$ & 0,6 & 0,9 & $\mathbf{2 , 0}$ & 1,5 & 2,6 \\
\hline MOLM-7_K & $\mathbf{0 , 2 5}$ & 0,19 & 0,31 & $\mathbf{0 , 1 5}$ & 0,11 & 0,19 \\
\hline MOLM-7_IR & $\mathbf{5 9 , 2}$ & 12,6 & 188,0 & $\mathbf{1 , 4}$ & 0,7 & 2,6 \\
\hline MOLM-7_DR & $\mathbf{9 2 , 7}$ & 35,7 & 783,8 & $\mathbf{3 6 , 7}$ & 26,3 & 55,7 \\
\hline K562_K & $\mathbf{0 , 2 5}$ & 0,12 & 0,42 & $\mathbf{0 , 3 4}$ & 0,25 & 0,47 \\
\hline K562_IR & $\mathbf{4 , 8}$ & 3,5 & 6,5 & $\mathbf{3 , 5}$ & 1,8 & 6,8 \\
\hline K562_DR & $\mathbf{5 , 2}$ & 2,9 & 9,3 & $\mathbf{3 , 6}$ & 1,7 & 7,5 \\
\hline
\end{tabular}

Table 2. EC50 values of imatinib and dasatinib effect on sensitive and resistant cells proliferation.

Cell lines were incubated with imatinib (range $0-100 \mu \mathrm{M}$ ) or dasatinib (range $0-100 \mathrm{nM}$ ). EC50 was defined as the TKI concentration that caused $50 \%$ reduction in proliferation/viability (as assessed by Alamar blue method). IR - imatinib-resistant cells, DR - dasatinib-resistant cells. EC50 values and confidence intervals ( $\mathrm{Cl}$ 95\%) were calculated from 2-3 independent experiments. 


\section{$\underline{\text { BCR-ABL transcript variants and mutations in the BCR-ABL kinase domain }}$}

To further characterize the novel cell lines, we verified the type of BCR-ABL transcript present in the cells. In MOLM-7 (both sensitive and resistant), the e13a2 (b2a2) transcript was present, and in JURL-MK1 and K562, e14a2 (b3a2) transcript was detected. The variant found in the parental line was always preserved in the derived resistant cells, no mutations were detected. A different situation was, however, observed via screening of the BCR-ABL kinase domain (KD) mutation status. The T315I mutation was present in all the resistant sublines derived from JURL-MK1 and MOLM-7 cell lines. On the other hand, K562 and its respective sub-lines remained without any mutation within the KD of BCR-ABL.

\section{Cytogenetics}

To verify the origin of the newly-established cells and to further demonstrate their possible difference from the original cell lines, cytogenetic characterization was performed. Detailed results are shown in Supplementary Figure S3.

In all JURL-MK1 derived cells, chromosomal aberrations were almost identical to their parental line. Only polyploid mitoses were present, and the BCR-ABL fusion signal was detected on the same chromosomes in all the three JURL-MK1 cell lines (Supplementary Figure S3A).

In TKI-sensitive MOLM-7 cells (Supplementary Figure S3B), structural changes relating to the BCR-ABL fusion gene were detected. The control cells had two extra numerical $\mathrm{Ph}$ chromosomes. In MOLM-7_IR cells, one extra numerical Ph was present, and a second one was translocated and amplified on the short arm of a derivative chromosome 13. MOLM7_IR cells were shown to be polyploid, and all BCR-ABL signals were present in two copies. In MOLM-7_DR cells, again, one extra numerical $\mathrm{Ph}$ chromosome was detected, and a second one was translocated to the short arm of chromosome 18. Additionally, in all MOLM7 cells, the BCR-ABL fusion signal was also detected on the short arm of chromosome 6. 
The K562 cells used in this study are near triploid and have characteristic markers reported for K562 in previous studies ${ }^{35,36}$. One copy of the chromosomes X, 3, 9, 13, and 14 was lost in all K562 cells. In all the three K562 cell lines the same abnormalities were present on several chromosomes (Supplementary Figure S3C). Additionally, some differences were detected. Results of fluorescence in-situ hybridization (FISH) with BCR-ABL specific probes showed that K562 and K562_DR (but not K562_IR) had BCR-ABL fusion on the short arm of the derivative chromosome 1. In K562 and K562_IR (but not K562_DR), this aberration was also found on the long arm of the derivative chromosome 22. In K562_IR, other nonamplified BCR-ABL fusions were detected on the long arms of the derivative chromosomes 2 and 5. In K562_DR, an additional BCR-ABL amplified signal was detected on the long arm of the derivative chromosome 11, and a non-amplified signal in the long arm of chromosome 16 and on the short arm of the chromosome X.

\section{$\underline{\text { BCR-ABL activity }}$}

The activity of the oncogene BCR-ABL was assessed via evaluating the phosphorylation status of CRKL, a surrogate marker of BCR-ABL activity. In JURL-MK1 and MOLM-7 TKI-resistant sub-lines, P-CRKL levels were increased compared to parental cells (Figure 3). In K562_IR cells, interestingly, CRKL phosphorylation was significantly decreased compared to their sensitive counterparts. In BCR-ABL negative cells, we were not able to detect a P-CRKL signal. 
bioRxiv preprint doi: https://doi.org/10 1101/2021.06.28.450156: this version posted June 28, 2021. The copyright holder for this preprint (which was not certified by peer review) is the author/funder, who has granted bioRxiv a license to display the preprint in perpetuity. It is made available under aCC-BY-NC-ND 4.0 International license.

A)

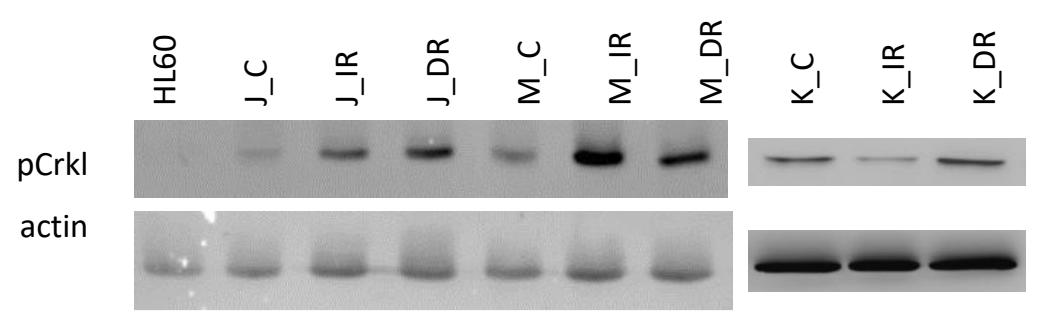

B

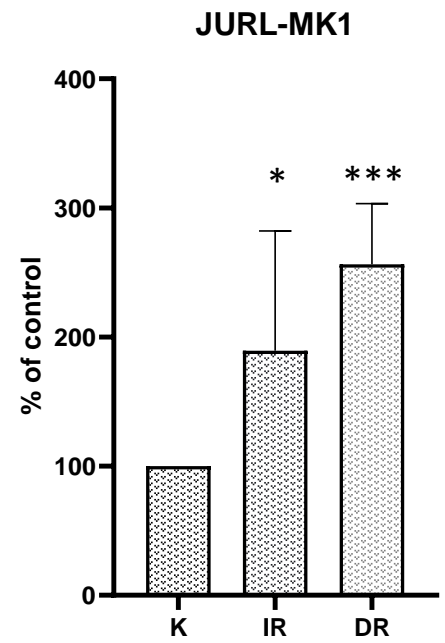

MOLM-7

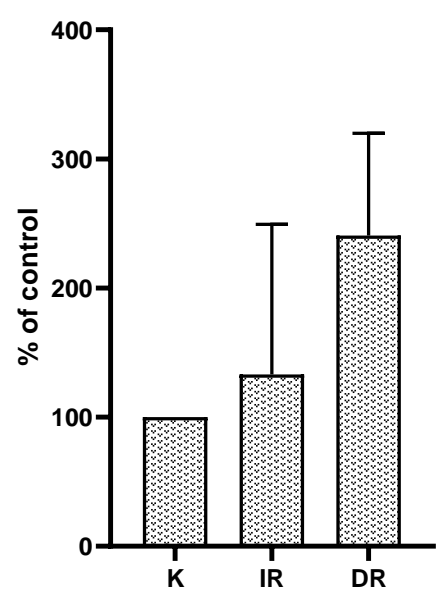

K562

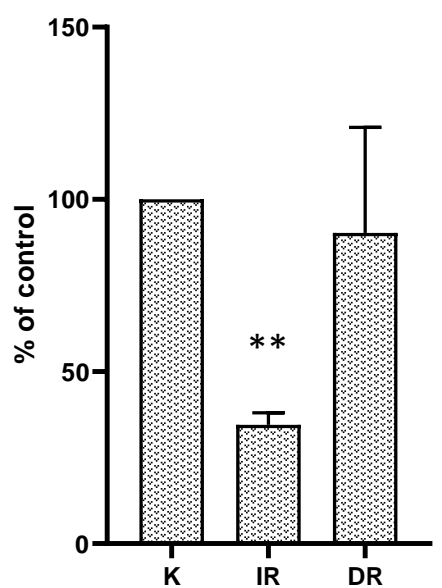

Figure 3 | BCR-ABL activity in TKI-resistant cells.

Representative western-blot image $(A)$ and relative densitometric graphs $(B)$ of phosphorylation of CRKL, a prominent substrate of BCR-ABL. Cell lines JURL-MK1 (J), MOLM-7 (M), and K562 (K) were used in all the three variants: control (_C), imatinib-resistant (_IR), or dasatinib-resistant (_DR). Actin was used as a loading control. Phosphorylation levels were normalised to $\beta$-actin and related to control. Means and standard deviation obtained from at least 3 biological replicates are shown. $\left({ }^{* * *} \mathrm{P}<0.001 ;{ }^{* *}\left(<0.01 ;{ }^{*} \mathrm{P}<0.05\right)\right.$.

\section{Phosphorylation of Ser226 of HSP90 correlates with CK2 kinase protein levels in CML}

\section{cell lines resistant to imatinib and/or dasatinib}

To verify the results obtained from protein arrays (Figure 1), we analyzed the level of HSP90 $\beta$ P-S226 in JURL-MK1 cells by western blotting (Figure 4). Indeed, the level of phosphorylated S226 of HSP90ß was significantly increased in both JURL-MK1 derived, 
TKI-resistant cell lines, compared to the sensitive parental cells (Fig 4A). We, therefore, assessed the expression of CK2 subunits and evaluated CK2 activity using a specific antibody for the detection of CK2 phosphorylated substrates (Fig 4B). Expression of CK2 $\alpha$ and $\beta$ subunits was significantly increased in both imatinib- and dasatinib-resistant JURL-MK1 cells and correlated with higher signals from CK2 specific phospho-substrate immunoblots (Figure 4C). In MOLM-7 derived sub-lines, only CK2 subunit beta and CK2 substrate phosphorylation were slightly increased in the resistant sub-lines, and no statistically significant difference was found between the parental line and the resistant sub-lines (Supplementary Figure S4A). Interestingly, in K562 resistant sub-lines, the amount of $\alpha$ and $\alpha^{\prime}$ decreased, as did the substrate phosphorylation (Supplementary Figure S4B).

Phosphorylation of the HSP90 co-chaperone CDC37 on S13 is known to be mediated by CK2 (Miyata and Nishida, 2005) and can be used as a marker of CK2 activity. Given the fact that CDC37 protein was phosphorylated at S13 in all the used cell lines (Supplementary Figure S4), it was used to assess the CK2 inhibition in subsequent experiments. 
A

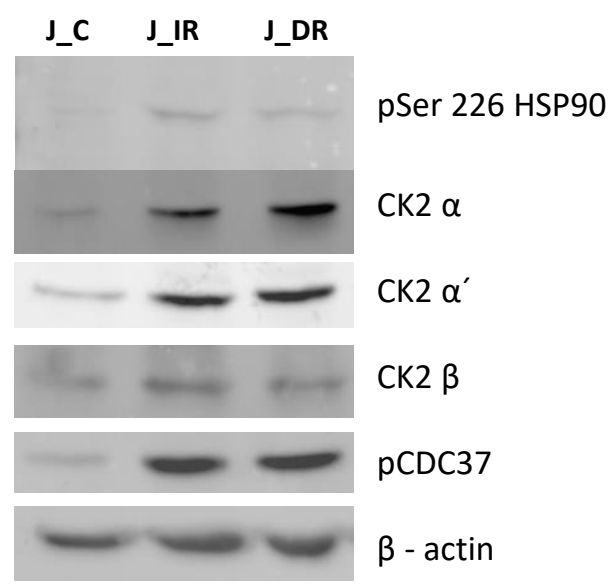

B

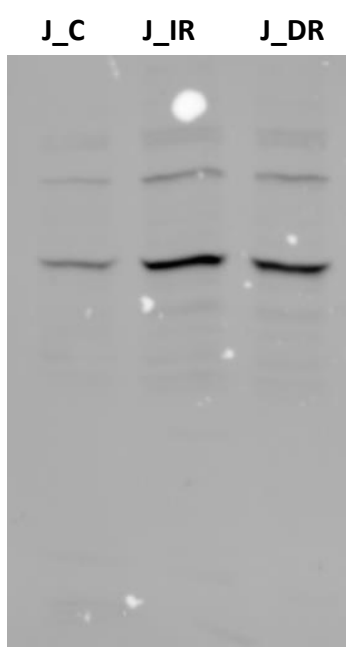

pCK2 Substrates

C
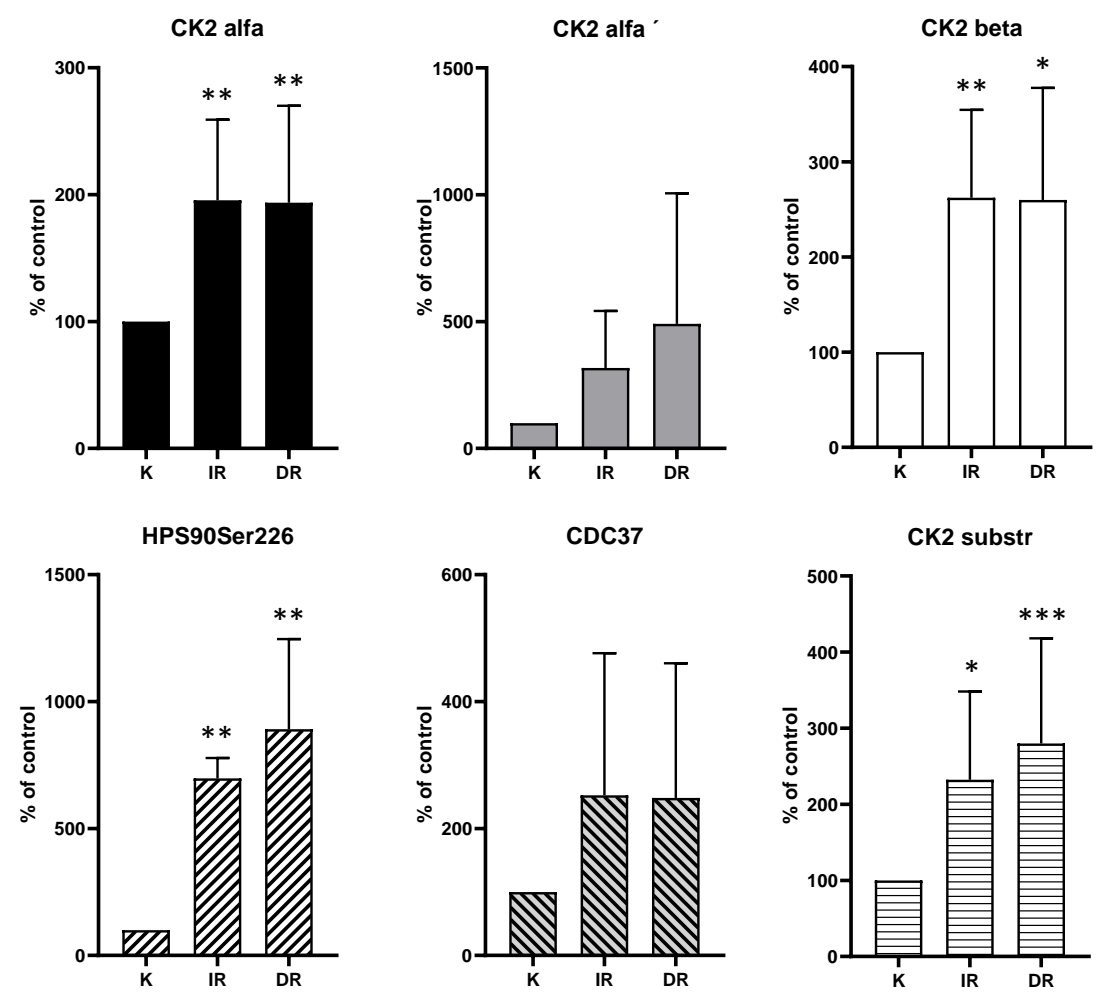

Figure 4 | CK2 protein subunit levels and substrate phosphorylation in sensitive and resistant cells.

Western blot analysis of JURL-MK1 cells and their resistant counterparts using antibodies against (A) CK2 subunits and known CK2 substrates, (B) CK2 consensus substrate sequence (pS/pT)DXE. Summary graphs from repeated experiments are presented in (C).

Protein/phosphorylation levels were normalised to $\beta$-actin and related to the corresponding controls. Means and standard deviation obtained from at least 3 biological replicates are shown. $\left({ }^{* * *} \mathrm{P}<0.001 ;{ }^{* *}\left(<0.01 ;{ }^{*} \mathrm{P}<0.05\right)\right.$. 


\section{Effects of CK-2 inhibition in CML cells}

We continued our studies by exploring the effect of CK2 inhibition in all the developed resistant CML cell lines. We performed viability assays using all inhibitors separately and also using CX-4945 in combination with each TKI. Based on literature ${ }^{37,38}$ and our own preliminary experience (Supplementary Figure S5), $10 \mu \mathrm{M} \mathrm{CX}-4945$ was used in all subsequent experiments (unless indicated otherwise).

\section{CK2 inhibition reduces cell proliferation and viability and induces apoptosis}

Cell metabolic health was measured by Alamar Blue, and changes induced by TKIs and CX4945 are shown in Figure 5A, B. While the effect of CX-4945 on all the parental CML cells (Figure 5A) was statistically significant, TKIs alone have a higher effect on cell proliferation than CX-4945. Importantly, the effect of CX-4945 was not affected by the newly acquired resistance, while the effects of TKIs were largely diminished in the resistant cell lines. Except for JURL-MK1 resistant sub-lines, we observed intensification of the cytotoxic effects of the inhibitors when used in combination (I+C and D+C columns), in MOLM-7_IR (D+C ) with significance $\mathrm{P}<0,05$ and in K562_IR (D+C) and K562_DR (both combinations of inhibitors) with significance $\mathrm{P}<0,01$. In BCR-ABL negative OCI-AML3 the effect of inhibitor combination was comparable to that of CX-4945 alone.

Similar results were observed for the cell count and dead cell fraction (shown in Figure 5C, D). While proven effective in the parental cell lines, TKIs failed to exhibit an appreciable effect on the resistant cells (Figure 5C). Interestingly, BCR-ABL negative OCI-AML3 cells were somewhat affected by CX-4945 treatment in terms of a slight growth slowing (Figure 5D), but CK2 inhibition did not induce an increase in the dead cell fraction in those cells. The other BCR-ABL negative control, HL-60, was unaffected (data not shown). 
bioRxiv preprint doi: https://doi.org/10.1101/2021.06.28.450156; this version posted June 28, 2021. The copyright holder for this preprint (which was not certified by peer review) is the author/funder, who has granted bioRxiv a license to display the preprint in perpetuity. It is made available under aCC-BY-NC-ND 4.0 International license.

We also observed PARP cleavage in cases where TKIs or CX-4945 had taken effect on cell proliferation or viability (Figure 5E, F). Interestingly, the levels of cleaved PARP in cells bearing T315I mutation (JURL-MK1 and MOLM-7 resistant sub-lines) are similar after CX4945 impact independently on its combination with TKIs. On the other hand in K562 cells were more affected by inhibitors combination comparing to inhibitors alone.

A
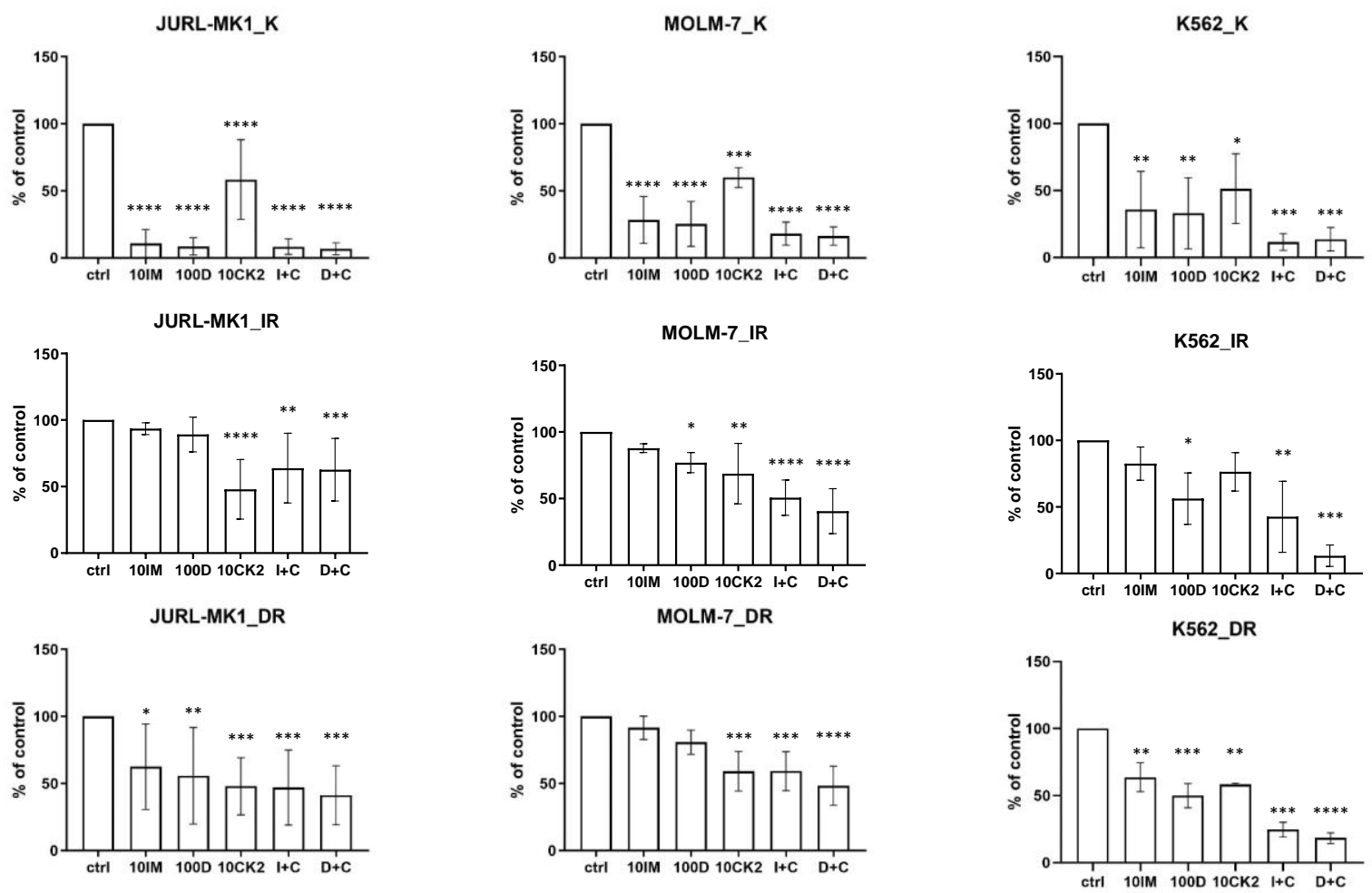
bioRxiv preprint doi: https://doi.org/10.1101/2021.06.28.450156; this version posted June 28, 2021. The copyright holder for this preprint (which was not certified by peer review) is the author/funder, who has granted bioRxiv a license to display the preprint in perpetuity. It is made available under aCC-BY-NC-ND 4.0 International license.

\section{B}
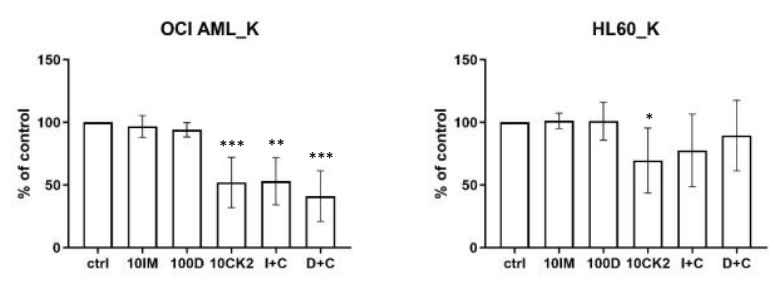

OCI AML_IR

HL60_IR
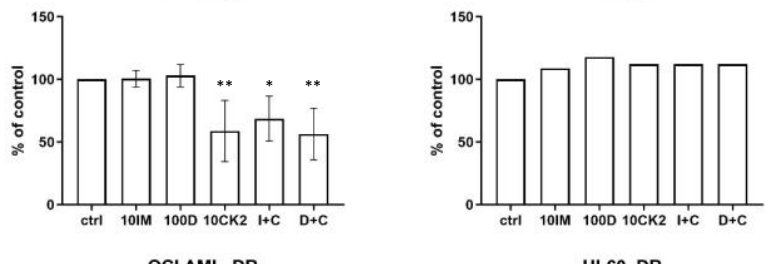

OCI AML_DR

HL60_DR
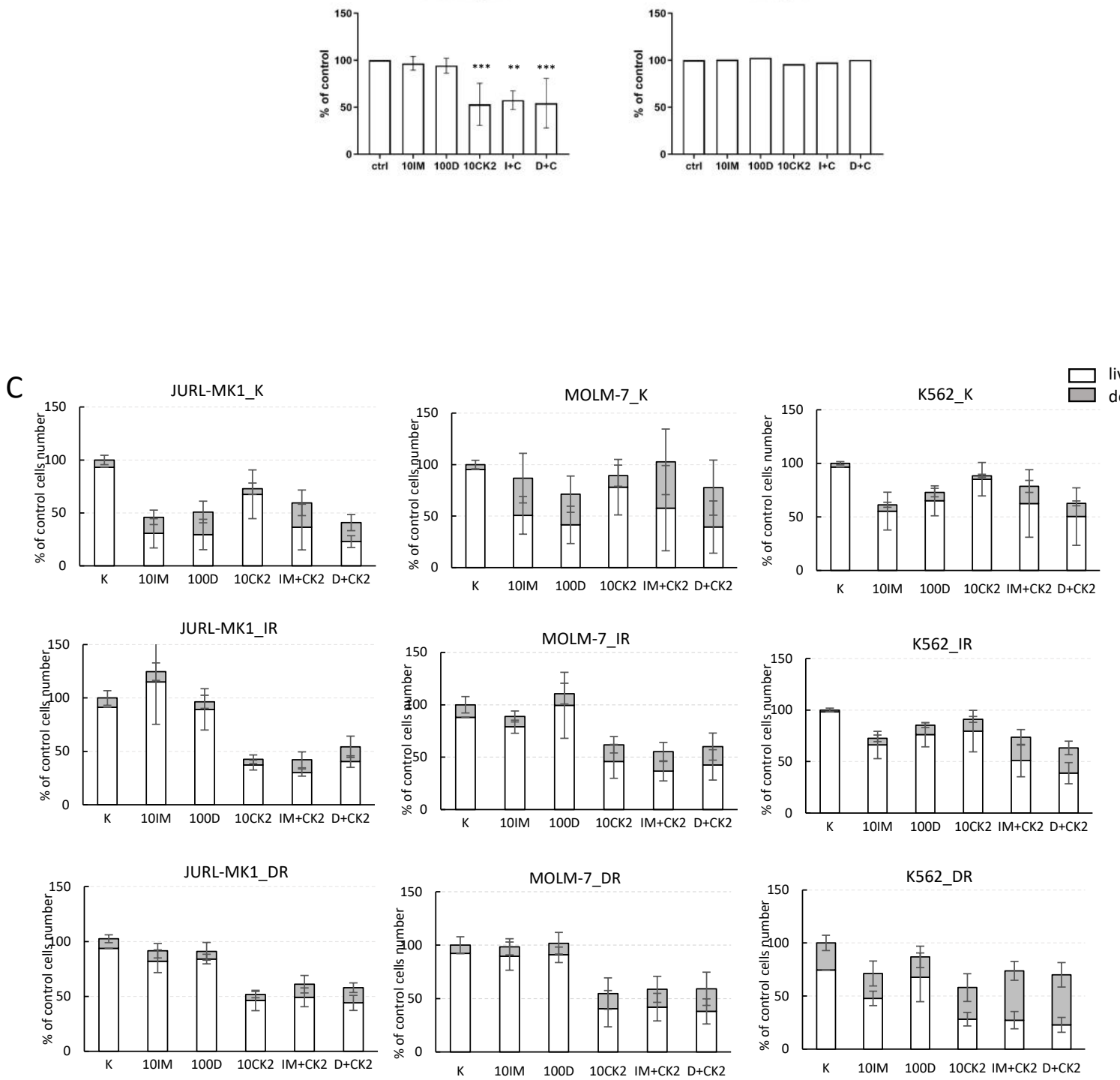
bioRxiv preprint doi: https://doi.org/10.1101/2021.06.28,450156; this version posted June 28, 2021. The copyright holder for this preprint (which was not certified by peer review) is the author/funder, who has granted bioRxiv a license to display the preprint in perpetuity. It is made available under aCC-BY-NC-ND 4.0 International license.

D
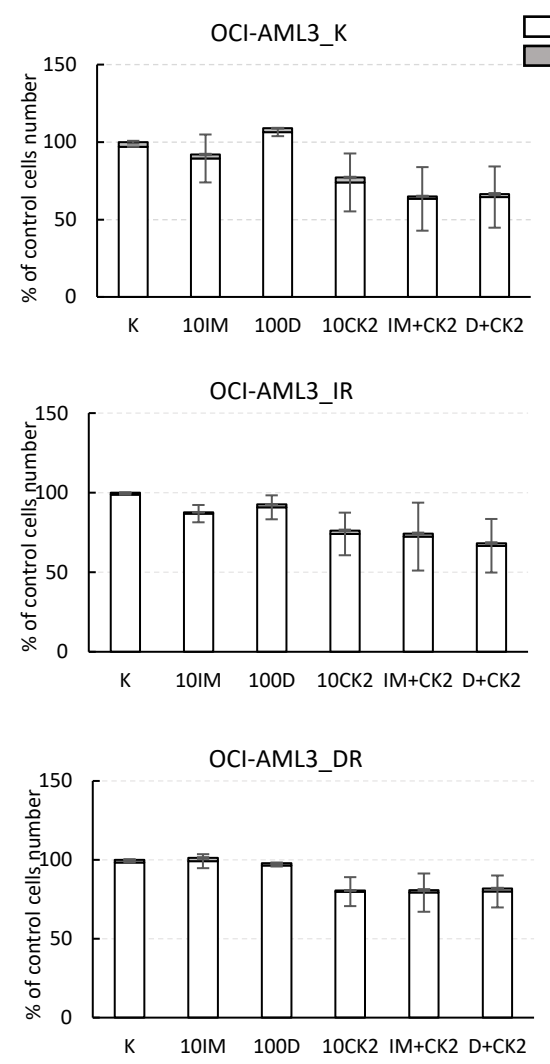

E

JURL-MK1

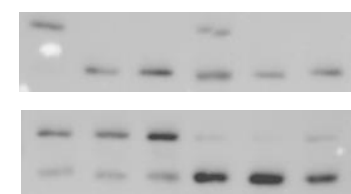

DR

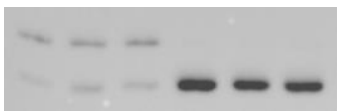

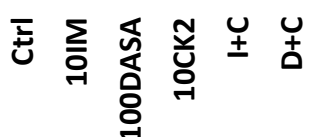

MOLM-7

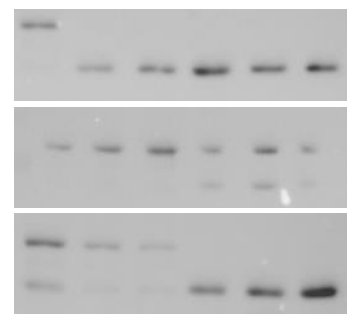

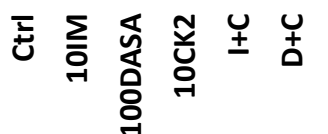

K562

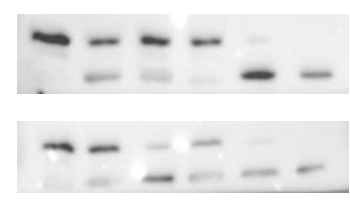

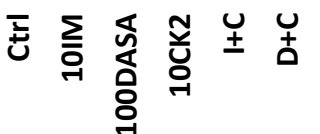

OCI-AML-3

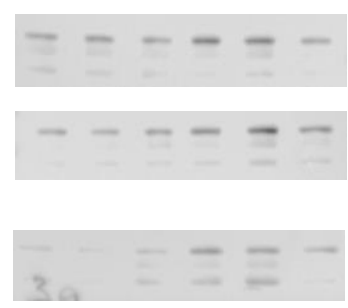

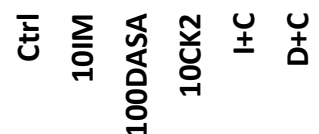


$\mathrm{F}$
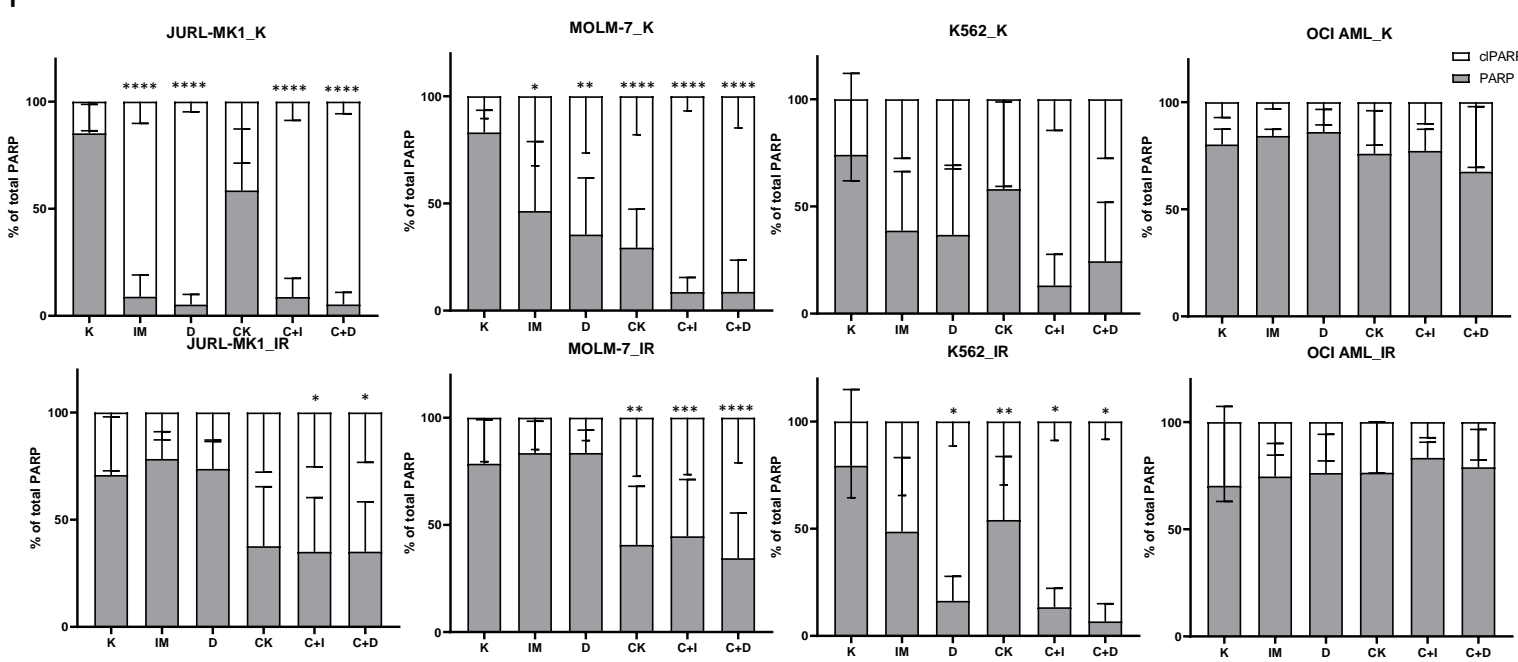

JURL-MK1_DR

MOLM-7_DR

K562_DR

OCI AML_DR
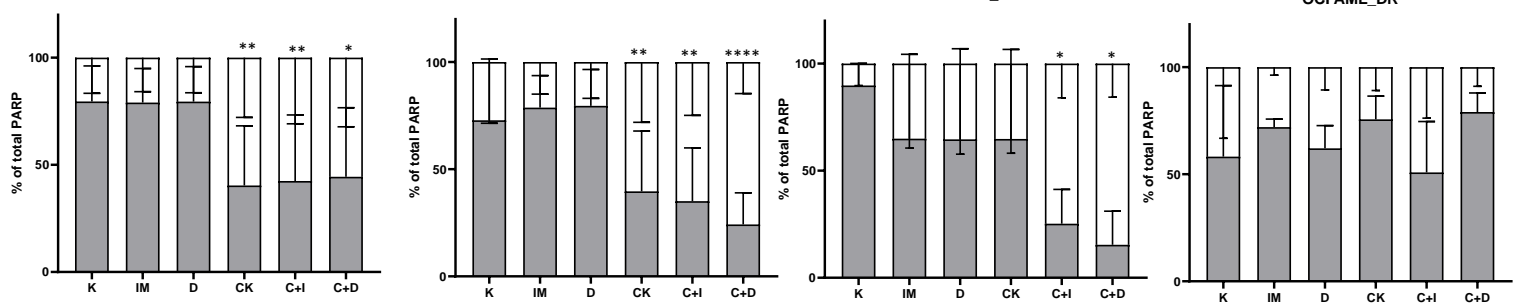

Figure 5 | Effects of CX-4945 on cell proliferation and viability.

The cells were treated for $48 \mathrm{~h}$ with imatinib $(10 \mu \mathrm{M})$, dasatinib $(100 \mathrm{nM}), \mathrm{CX}-4945(10 \mu \mathrm{M})$, and their combinations.

Proliferation/cell activity of BCR-ABL positive (A) and BCR-ABL negative (B) cells was assessed by the Alamar blue method and related to the control. The data represents mean with SD of $3-6$ separate experiments, statistical significance was assessed by one-way ANOVA followed by a Dunnett's multiple comparisons test $\left({ }^{*} p<0.05,{ }^{* *} p<0.01,{ }^{* * *} p<0.001,{ }^{* * *} p<0.0001\right)$.

Cell numbers and viability (C, D) were evaluated by trypan blue staining; apoptosis was tested via cleaved PARP1 by western blots.

Representative western blots (E) and density graphs (F) of PARP/cIPARP are presented. Means and standard deviation obtained from at least 5 experiments ( 3 independent biological replicates, each at least 2 times analysed by western blot) are shown. $\left({ }^{* * * *} P<0,0001,{ }^{* * *} P<0.001,{ }^{* *} P<0,01\right.$, $\left.{ }^{*} \mathrm{P}<0.05\right)$

(C - control, IR - imatinib-resistant, DR - dasatinib-resistant) 


\section{CK2 participates in resistance to both imatinib and dasatinib.}

There are opposing views on the issue of how CK2 and BCR-ABL regulate each other ${ }^{39,40}$. We aimed to evaluate the relationship of those kinases in our new cell models. To grasp this concept, we utilized the prominent substrates for CK2 and BCR-ABL, the proteins CDC37 and CRKL, and assessed changes in their phosphorylation after inhibitor treatment (Figure 6).

CRKL. According to expectation, TKIs had a profound and significant effect on CRKL phosphorylation in sensitive cells, while CX-4945 did not change the P-CRKL levels at all. In resistant cells, CRKL phosphorylation in JURL-MK1_IR/DR and MOLM-7_IR / DR cells remained unchanged upon inhibitor treatment. This was expected, since those cells carry the T315I mutation, rendering them resistant to most TKIs. K562_IR cells show a very similar PCRKL response to TKIs as their respective parental cells, which indicates that their resistant phenotype is driven by activation of other pathway(s). Notably, the effect of imatinib on CRKL phosphorylation was lower than that of dasatinib.

CDC37. The mutual effect of CK2 and BCR-ABL inhibition was also observed via monitoring the CK2 activity, assessing the phosphorylation of CK2 substrate CDC37 S13. After CX-4945 (alone or in combination) treatment, a high decrease of phosphorylation was seen mainly in MOLM-7 cells including the resistant sublines. Importantly, TKI used alone usually significantly decreased CDC37 phosphorylation in TKI-sensitive cells, but not in the resistant sublines, indicating that $\mathrm{BCR}-\mathrm{ABL}$ is involved in CK2 activity in CML cells. 


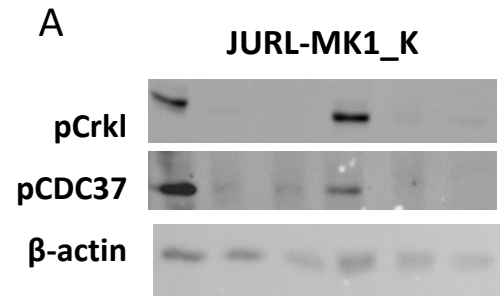

\section{MOLM-7_K}

pCrkl pCDC37

$\beta$-actin

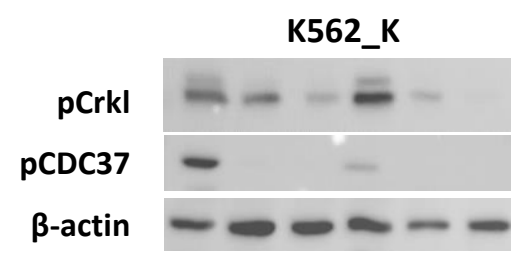

JURL-MK1_IR

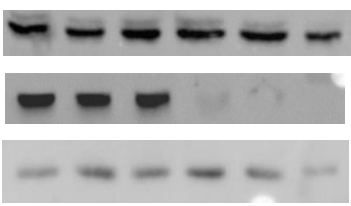

MOLM-7_IR

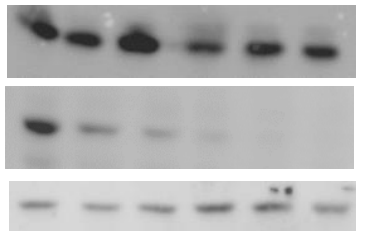

K562_IR

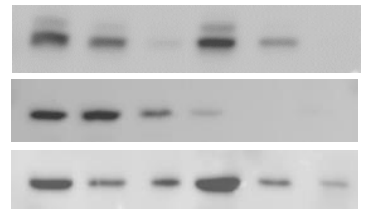

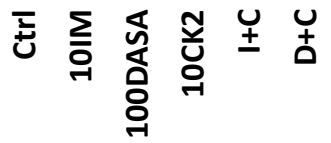

PCRKL

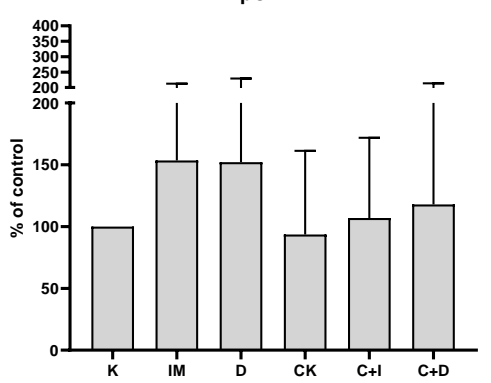

CDC37

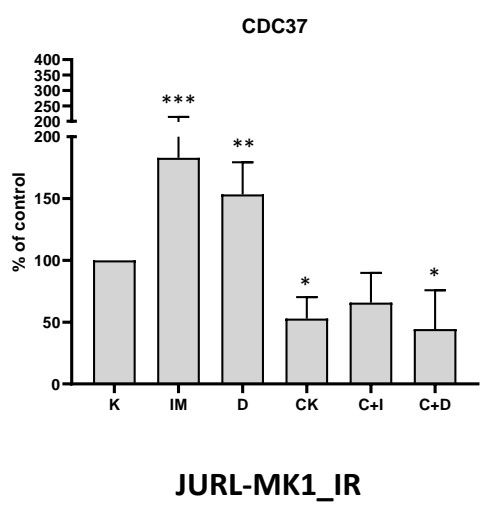

JURL-MK1_IR
JURL-MK1_DR

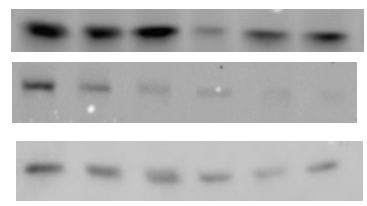

MOLM-7_DR

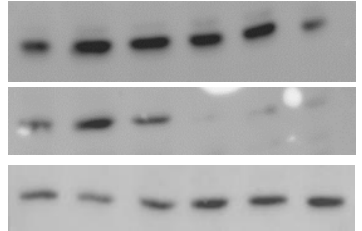

K562_DR

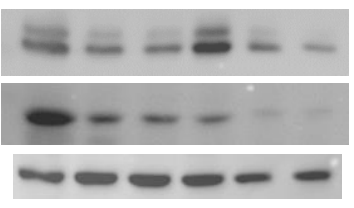

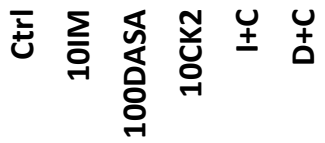

B
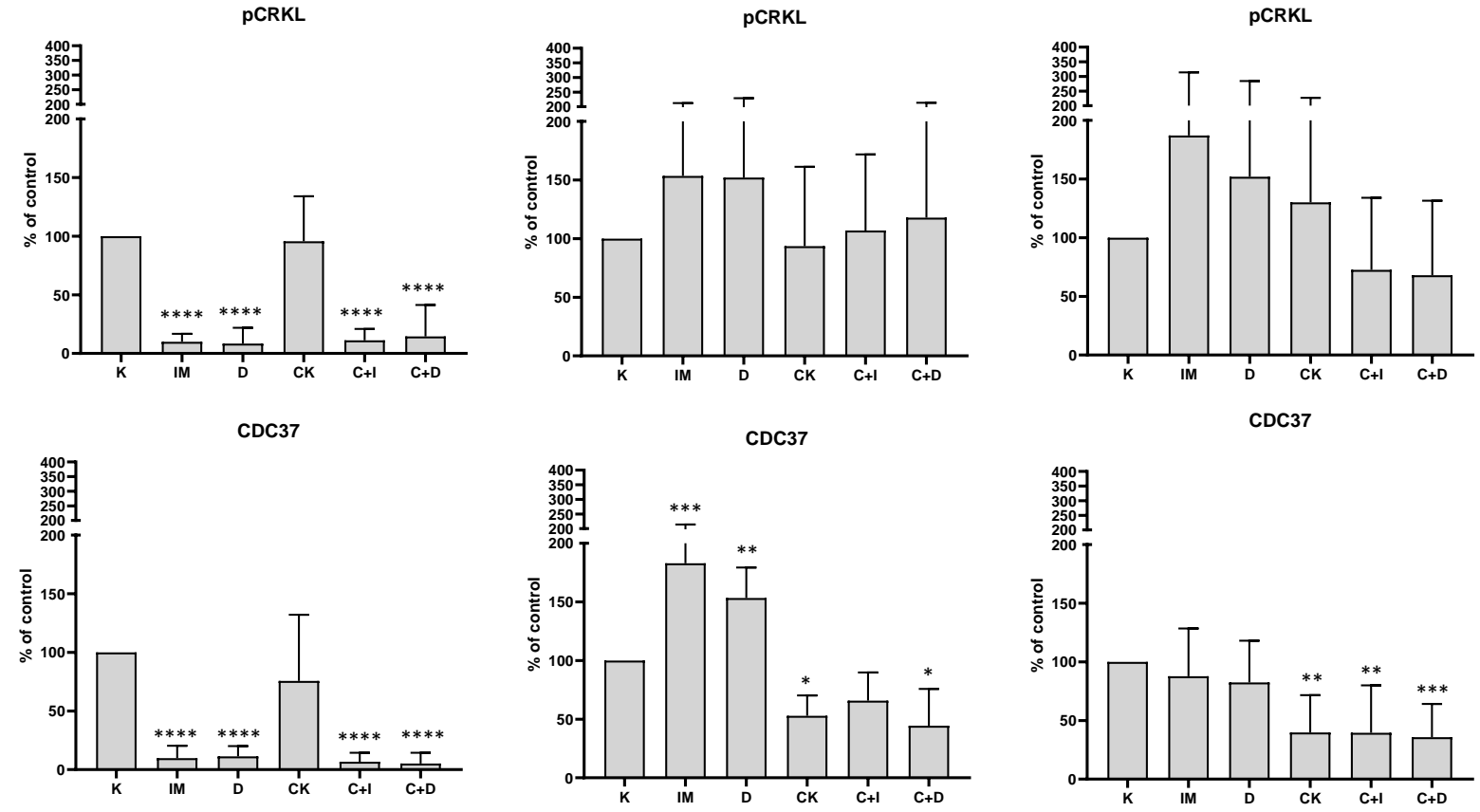

JURL-MK1_K

JURL-MK1_DR 


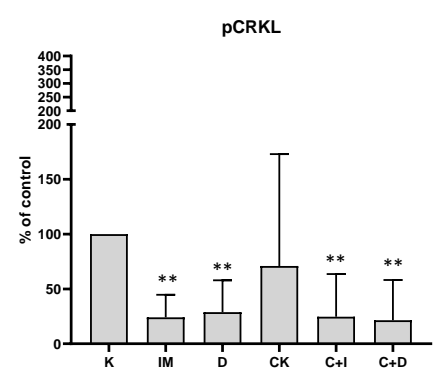

$\operatorname{CDC37}$

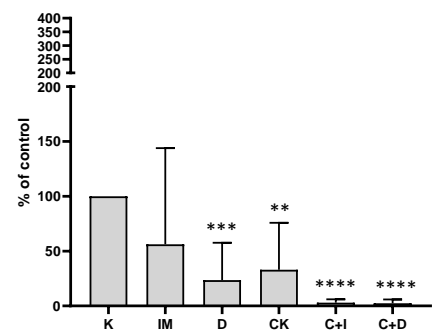

MOLM-7_K
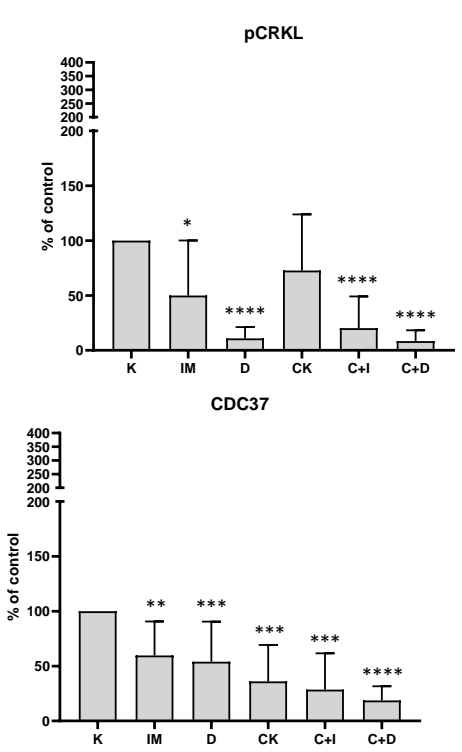

K562_K

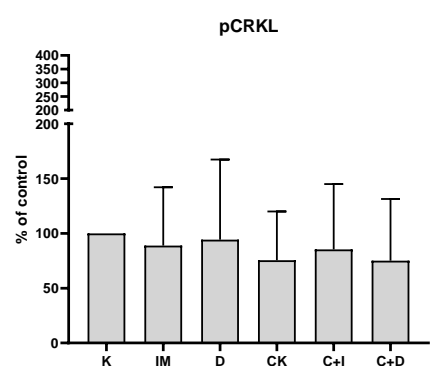

CDC37

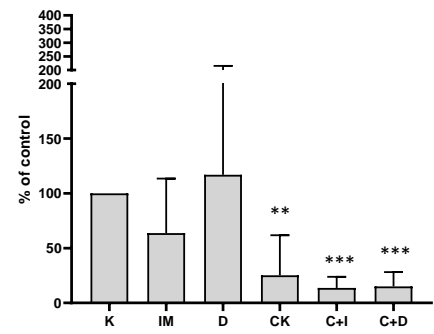

MOLM-7_IR
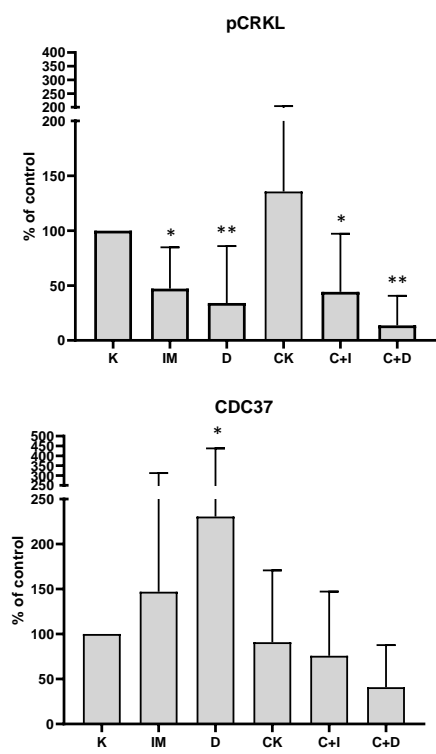

K562_IR

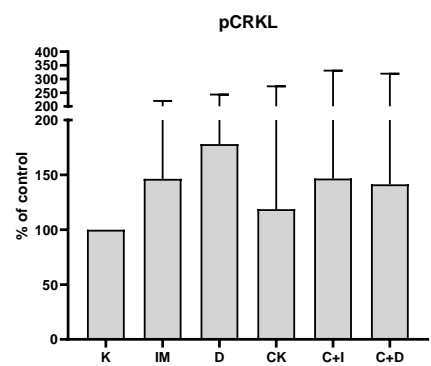

CDC37

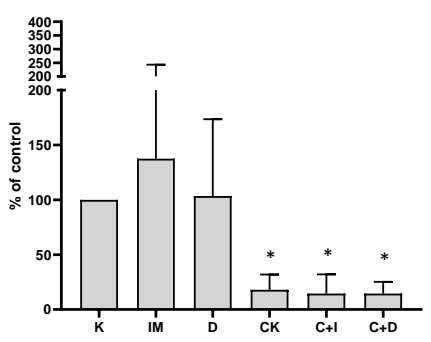

MOLM-7_DR
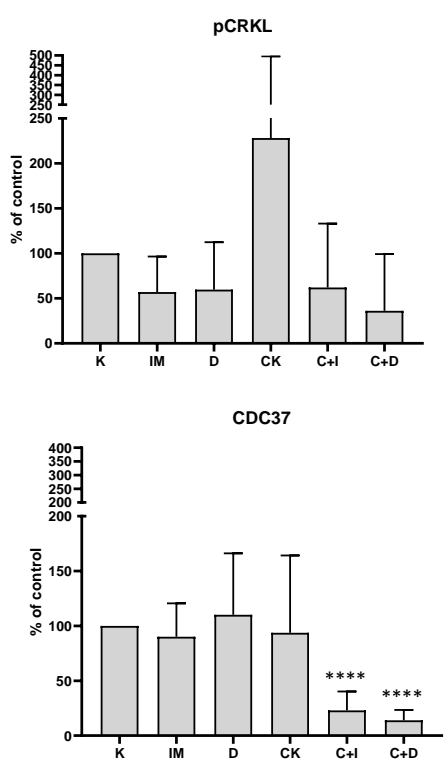

K562_DR

Fig. 6 | Effects of CX-4945 and TKIs on CK2 and BCR-ABL substrate phosphorylation.

The cells were treated for $48 \mathrm{~h}$ with imatinib $(10 \mu \mathrm{M})$, dasatinib $(100 \mathrm{nM}), \mathrm{CX}-4945(10 \mu \mathrm{M})$, and their combinations. Western blot analyses of their effect to CK2 and BCR-ABL substrate phosphorylation, CDC37 and Crkl respectively, on CML cell lines are shown.. C - controls, IR - imatinib resistant, DR dasatinib resistant. Representative western blots $(A)$ and density graphs $(B)$ are presented. Means and standard deviation obtained from at least 6 experiments ( 3 biological replicates, each at least 2 times analysed by western blot). are shown. $\left({ }^{* * * *} P<0,0001,{ }^{* * *} P<0.001,{ }^{* *} P<0,01,{ }^{*} P<0.05\right)$ (C - control, IR - imatinib-resistant, DR - dasatinib-resistant) 
bioRxiv preprint doi: https:/doi.org/10.1101/2021.06.28.450156: this version posted June 28, 2021. The copyright holder for this preprint (which was not certified by peer review) is the author/funder, who has granted bioRxiv a license to display the preprint in perpetuity. It is made available under aCC-BY-NC-ND 4.0 International license.

\section{CK2 inhibition decreases viability and induces apoptosis of primary CML cells}

To assess the effects of CK2 inhibition in primary CML cells, we collected samples from 2

CML patients without a satisfactory response to any of the TKIs used in clinical practice (imatinib, nilotinib, dasatinib, bosutinib) and without any mutation in the BCR-ABL kinase domain (for patient characteristics, see Table 3). Primary cells were incubated with inhibitors at the same concentrations as in the case of cell lines (imatinib $10 \mu \mathrm{M}$, dasatinib $100 \mathrm{nM}$, and CX-4945 $10 \mu \mathrm{M}$ ) for $48 \mathrm{~h}$. As expected, due to the treatment failure, cell viability was only slightly decreased after the exposition of patients' leukocytes to imatinib and dasatinib (Figure 7A). Interestingly CX-4945 decreased cell activity in the case of patient No.1. We further tested the possibility of inhibitors synergy and analyzed changes of activity in primary cells of patient no. 2 and of healthy donors. Cells were incubated with imatinib, dasatinib, CX-4945, and in addition to the combination of CX-4945 with TKIs (Figure 7B). The combination of CX-4945 with TKI highly decreased proliferation which supported synergism between both inhibitors. CX-4945 did not significantly affect the cells taken from healthy donors (Figure 7).
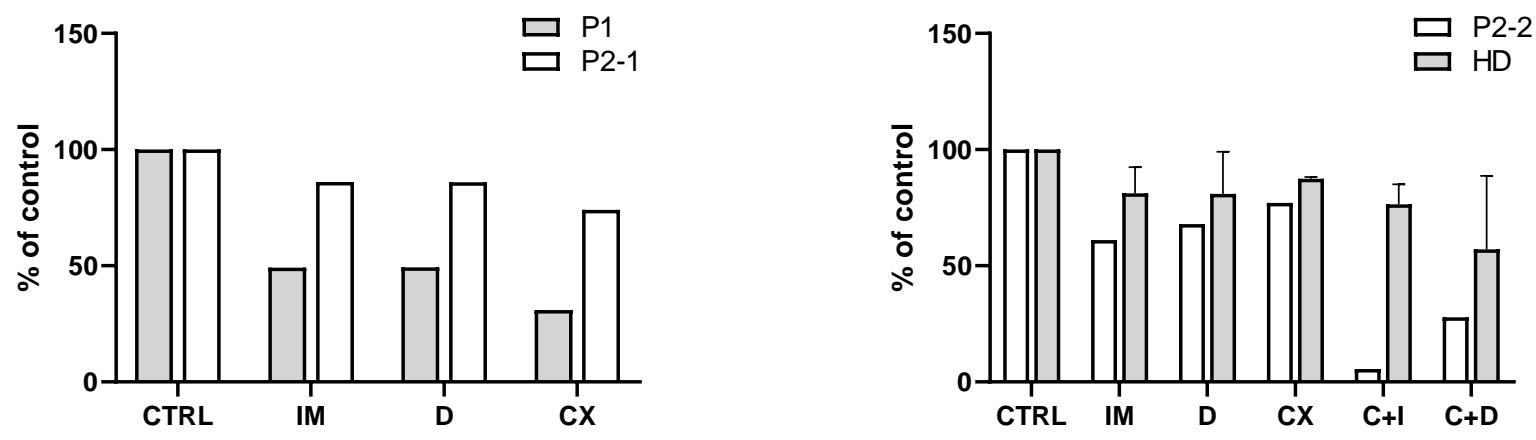

Fig. 7 | Effects of CX-4945 on primary cells proliferation and viability.

Patient cells (P1, P2-1) and healthy donors (HD) were incubated for $48 \mathrm{~h}$ with $10 \mu \mathrm{M}$ imatinib, $100 \mathrm{nM}$ dasatinib, and $10 \mu \mathrm{M} \mathrm{CX}-4945$; primary cells of patient no 2 (P2-2 - second analysis) and healthy donors were in addition incubated with mentioned inhibitors and with their combination as indicated. The effects were assessed by means of AlamarBlue. 
bioRxiv preprint doi: https://doi org/10.1101/2021.06.28.450156: this version posted June 28,2021 . The copyright holder for this preprint (which was not certified by peer review) is the author/funder, who has granted bioRxiv a license to display the preprint in perpetuity. It is made available under aCC-BY-NC-ND 4.0 International license.

\begin{tabular}{|c|c|c|c|c|c|c|c|c|c|}
\hline \multicolumn{10}{|c|}{ Basic characteristics of patients } \\
\hline & \multirow[b]{2}{*}{ Sex } & \multirow{2}{*}{$\begin{array}{c}\text { Age at } \\
\text { DG } \\
\text { (years) }\end{array}$} & \multicolumn{7}{|c|}{ at time of analysis } \\
\hline & & & $\begin{array}{l}\text { Months } \\
\text { from DG }\end{array}$ & $\begin{array}{c}\text { BCR-ABL } \\
(\%)\end{array}$ & $\begin{array}{c}\text { WBC } \\
10^{\wedge 9 / L}\end{array}$ & $\begin{array}{c}\text { PLT } \\
10^{\wedge 9 / L}\end{array}$ & $\begin{array}{c}\text { blasts } \\
(\%)\end{array}$ & therapy & aberations \\
\hline P1 & $M$ & 49 & 199,5 & 30 & 11,29 & 171 & & bosutinib & \\
\hline \multirow{2}{*}{ P2 } & \multirow{2}{*}{ M } & \multirow{2}{*}{61} & 93 & 7,6 & 49,4 & 52 & & nilotinib & \multirow{2}{*}{$+8, \operatorname{der}(22) t(9 ; 22)(q 34 ; q 11)$} \\
\hline & & & 102 & 151 & 6,05 & 132 & 7,4 & bosutinib & \\
\hline
\end{tabular}

Table 3. Characteristics of patients included in ex vivo experiments.

The effect of TKIs and CX-4945 was tested ex vivo in total of two patients without adequate response to any therapy. Table shows parameters at time of analysis:

DG — diagnosis, therapy: imatinib / dasatinib / nilotinib, BCR-ABL \% - mRNA level, WBC — white blood cell count, PLT — platelet count, blasts — \% of blast cells in total cell count in sample.

\section{Discussion}

Casein Kinase 2 (CK2) is important in the regulation of proliferation, differentiation, glucose uptake, adhesion, and migration ${ }^{41-44}$. It is overexpressed in many malignancies, both hematological and solid. CK2 is not, however, considered an oncogene, since its overexpression itself is usually not sufficient for cancer development. However, it creates a cancer-supporting environment, driving the cells into a state of non-oncogene addiction ${ }^{45}$. Cancer cells are indeed more sensitive to CK2 inhibition than their healthy counterparts, as it was shown also in several hematological malignancies ${ }^{46-48}$.

In CML, CK2 interacts with BCR-ABL ${ }^{39,40}$, and imatinib-resistant cells seem to be sensitive to CK2 inhibitor CX-4945 ${ }^{32,33,49}$. CK2, therefore, represents a possible therapeutic target ${ }^{50}$. We add to this discussion showing that CX-4945 can also be effective in dasatinib-resistant cells.

We have previously shown that increased HSP90 levels correlate with negative outcomes in the CML course and response to therapy ${ }^{51}$. CK2 phosphorylates HSP90 on several sites, regulating the interaction of HSP90 with its co-chaperone, cell division cycle 37 
(CDC37) ${ }^{52-54}$. Changes in HSP90 $\beta$ phosphorylation (both hyperphosphorylation and hypophosphorylation) are associated with TKI resistance in CML ${ }^{55-57}$.

Here, we found the HSP90 $\beta$ S226 to be hyperphosphorylated specifically in patients with poor response to TKI treatment. The ratio of HSP90 $\beta$ P-S226 to total HSP90 was markedly increased even after one year of treatment in a patient not responding to therapy (Figure 1B). Since the availability of patient samples is limited, we developed six new, CML-derived cell lines resistant to TKIs. We characterized these cells as to their cytogenetic profile, BCR-ABL activity, TKI cross-resistance, growth, and protein profiling, and the results given in Figures 2-4, S2, and S3 clearly show differences among these sub-lines, indicating differences in TKI resistance mechanisms. The majority of clinical TKI resistance is caused by mutations in the BCR-ABL gene ${ }^{58}$, and T315I mutation detected in all our JURL-MK1 and MOLM-7 TKIresistant variants (Figure 4) illustrates the importance of this gatekeeper mutation in the process. On the other hand, similarly to other laboratory findings ${ }^{59,60}$, resistant sub-lines derived from the K562 cell line did not develop any mutation in the BCR-ABL kinase domain. This fact, together with the lack of overactivation of P-CRKL (Figure 3) suggests a resistance mechanism independent of BCR-ABL in these cells.

Growth characteristics (Supplementary Figure S2) together with proliferation analyses (Figure 2, Table 2) demonstrate that all the resistant cells decreased their sensitivity to TKIs as compared to their sensitive counterparts. The observed cross-resistance (insensitivity of the cells to another TKI than that used for resistance acquisition) confirms that the resistance mechanisms developed under the selective pressure of one inhibitor often provide resistance to other TKIs as well ${ }^{61}$.

Changes detected by cytogenetic analysis (Figure S3) involved amplification of BCR-ABL fusion signal in several resistant cell lines, suggesting upregulation of BCR-ABL expression. 
Indeed, the levels of P-CRKL in untreated cells (Figure 3) corresponds to a potentially higher amount of BCR-ABL in the resistant JURL-MK1 and MOLM-7 cells. A higher amount of BCR-ABL fusions in MOLM-7 and K562 cells comparing to JURL-MK1 cells could explain a slower decrease of CRKL phosphorylation after TKI incubation (Figure 6).

CK2 subunit protein expression in resistant cells compared to their sensitive counterparts was variable among cell lines, the protein levels correlated with changes in CK2 substrate phosphorylation levels (Figure 4 and Supplementary Figure S4) and also with the effect of CX-4945 on apoptosis (Figure 5A) and cell activity (Figure 6 C, F). Nevertheless, the effect of CK2 inhibition was seen in all cell lines.

In the resistant sub-lines with the T315I mutation, the main role of BCR-ABL in TKI resistance is evident and supported by many years of clinical experience. However, targeting CK2 with CX-4945 resulted in a decrease in cell viability and subsequent induction of cell death in most of the CML cells used in our study (Figure 5) while BCR-ABL signaling remained active in all cells after CK2 inhibition (Figure 6). This indicates that while active BCR-ABL kinase is not affected by the CK2 activity decrease, the effects on cell proliferation and the increase of apoptotic parameters support the non-oncogene addiction hypothesis in CML cells. This suggests that CK2 inhibition may help to overcome CML resistance to TKIs.

In K562 cells, where the T315I mutation is not present, CK2 kinase is also evidently involved in mechanisms of TKI resistance. After CX-4945 treatment, there is only a partial decrease of cell proliferation and viability, which becomes more significant in combination with TKIs (Figure 5A). Potential candidate molecules to mediate K562 resistance are Src family kinases (SFK), which are recognized as important players in TKI resistance ${ }^{62,63}$. It is known that SFKs activate CK2 ${ }^{64}$, and CK2 can inactivate SFK via feedback loop ${ }^{65}$. Thus, inhibition of 
CK2 potentially enables SFK activity, which can also be responsible for increased P-CRKL levels in the resistant K562 cells treated with CX-4945 (Figure 6B).

As we and others have previously shown ${ }^{66-68}$, results of in vitro/ex vivo cultivation of isolated patient leukocytes with TKIs correlate well with therapy results and are of a great prognostic value. Similarly, in vitro experiments with CK2 inhibitors could predict the role of CK2 in resistance to TKI and thus a possibility to target CK2 kinase. CK2 inhibition did not affect leukocytes from healthy donors (Figure 7), which corresponds to previous reports ${ }^{69}$. On the other hand, CK2 inhibition alone or in combination with TKI decreased the metabolic activity of primary cells of CML patients with resistance to various TKI (Table 3).

In conclusion, we present a study of the effects of CK2 inhibition on TKI-resistant CML cells. Using six originally developed cell lines resistant to tyrosine kinase inhibitors as well as primary patients' samples, we showed that CK2 inhibition and/or its combination with TKIs is capable of inducing cell death in TKI-resistant cells. This is true even for cells bearing the gatekeeper T315I mutation. Importantly, BCR-ABL negative cell line HL60 and primary cells from healthy donors remain unaffected by such treatment.

We believe that the experiments described in this study will contribute to putting the rationale for further exploration of $\mathrm{CK} 2$ role in CML, with the aim of the introduction of CK2 targeting into clinical practice.

\section{Material and methods}

\section{$\underline{\text { Patient samples and cell cultures }}$}

Leukocytes from CML patients and healthy donors were isolated as described previously ${ }^{51,68}$. Responses to therapy were defined according to European Leukemia Net (ELN) classification ${ }^{29}$. Samples were obtained with the agreement of the Ethics Committee of the Institute of Hematology and Blood Transfusion (Prague, Czech Republic) according to the Declaration of Helsinki. Written informed consent was obtained from all patients. 
bioRxiv preprint doi: https:/doi.org/10.1101/2021.06.28.450156: this version posted June 28, 2021. The copyright holder for this preprint (which was not certified by peer review) is the author/funder, who has granted bioRxiv a license to display the preprint in perpetuity. It is made available under aCC-BY-NC-ND 4.0 International license.

BCR-ABL positive cell lines JURL-MK1, MOLM-7, and K562, as well as BCR-ABL negative HL60 and OCIAML3 cell lines, were used in this study.

From all the BCR-ABL positive cell lines, sub-lines resistant either to $2 \mu \mathrm{M}$ imatinib or $2 \mathrm{nM}$ dasatinib were raised according to the protocol by Mahon et al. (2000). Briefly, resistant cells were developed by serial prolonged exposures of parental cells to gradually increasing concentrations of imatinib and dasatinib, starting from $1 \mathrm{nM}$ to $2 \mu \mathrm{M}$ (imatinib) and $1 \mathrm{pM}$ to $2 \mathrm{nM}$ (dasatinib). Parental cell lines were cultivated in parallel without inhibitors. All cells were incubated at $37{ }^{\circ} \mathrm{C}$ in RPMI medium with $10 \%$ fetal bovine serum and antibiotics ${ }^{51,68}$.

\section{Chemicals and antibodies}

Imatinib mesylate, nilotinib, dasatinib, and CX-4945 were purchased from Santa Cruz Biotechnology, Inc. All inhibitors were dissolved as $10 \mathrm{mM}$ stock solution in DMSO (Sigma-Aldrich Inc., Missouri, USA), stored at -20 ${ }^{\circ} \mathrm{C}$, and then diluted in the culture medium to the final concentrations used in each experiment. Protease inhibitor cocktails and Phosphatase inhibitor cocktails were purchased from Calbiochem and SIGMAALDRICH, respectively. Non-conjugated primary antibodies HSP $90 \alpha / \beta$ Antibody (F-8), HSP 90 $\alpha$ Antibody (C-20), HSP $90 \beta$ Antibody (D-19), casein kinase II $\alpha$ (D-10 and E-7), casein kinase II $\alpha^{\prime}$ Antibody (E-7), and casein kinase II $\beta$ Antibody (6D5) were purchased from SantaCruz Biotechnology (Santa Cruz, CA, USA). AntiHsp90 beta (phospho S226) antibody was purchased from Abcam (Abcam, UK). Phospho-CK2 Substrate [(pS/pT)DXE] MultiMab ${ }^{\text {TM }}$ Rabbit mAb, Phospho-CDC37 (Ser13) (D8P8F) Rabbit mAb, Phospho-CrkL (Tyr207) Rabbit mAb, Cleaved PARP (Asp214) (D64E10) XP, and HRP conjugated secondary antibodies were purchased from Cell Signaling Technology (Cell Signaling Technology, Inc., Danvers, MA, USA). Actin (antiactin antibody clone AC-15, SIGMA-ALDRICH) or beta-tubulin ( $\beta$-Tubulin (9F3) were purchased from SantaCruz Biotechnology (Santa Cruz, CA, USA).

\section{$\underline{\text { In vitro incubation with inhibitors }}$}

CML cell lines and primary cells were incubated for the appropriate time interval at $37^{\circ} \mathrm{C}$ in RPMI medium with $10 \%$ fetal bovine serum and antibiotics, in the presence or the absence of $10 \mu \mathrm{M}$ imatinib or $100 \mathrm{nM}$ dasatinib, and/or $10 \mu \mathrm{M} \mathrm{CK} 2$ kinase inhibitor CX-4945.

\section{$\underline{\text { EC50 analyses }}$}

Sensitive and resistant cells were incubated with imatinib (up to $100 \mu \mathrm{M}$ ) or dasatinib (up to $100 \mathrm{nM}$ ). EC50 values were established based on the cell viability data (see further) using the GraphPad Prism 8.2 program. 
bioRxiv preprint doi: https:/doi.org/10.1101/2021.06 28.450156; this version posted June 28, 2021. The copyright holder for this preprint (which was not certified by peer review) is the author/funder, who has granted bioRxiv a license to display the preprint in perpetuity. It is made available under aCC-BY-NC-ND 4.0 International license.

\section{Cell viability, metabolic activity assays}

Cell viability was assessed by Trypan blue staining (according to the manufacturer's protocol); cell metabolic activity was evaluated using the AlamarBlue ${ }^{\circledR}$ assay (Invitrogen), following the manufacturer's instructions. Briefly, $100 \mu \mathrm{L}$ of cell suspension was transferred to a 96-well plate and $10 \mu \mathrm{L}$ of AlamarBlue reagent was added to each well. The plate was incubated at $37^{\circ} \mathrm{C}$ for 1 hour, fluorescence intensity was subsequently measured on microplate reader BMG FLUOstar Galaxy (MTX Lab Systems, Inc., VA, USA).

\section{Cell apoptosis}

Cell death was assessed using western blot analysis of PARP1 cleavage.

\section{Western blotting}

Western blot analyses were performed as described previously ${ }^{68}$. Briefly, cells were harvested, lysed in Laemmli buffer, and boiled for 10 minutes. The samples were resolved on sodium dodecyl sulfatepolyacrylamide gel (10\%), transferred to PVDF or nitrocellulose membrane, and incubated with the appropriate antibodies. Protein bands were detected by chemiluminescence (SuperSignal West Dura Extended Duration Substrate -Thermo Fisher Scientific, USA) and scanned using a G:BOX imager (Syngene Europe).

Densitometric quantification was performed using Gene Tools product version: 4.3.8.0 (Syngene Europe). All analyses were repeated 2- 5 times.

\section{Determination of BCR-ABL transcript variants and mutations}

\section{RNA isolation, $R T-P C R$, and real-time RT-PCR}

Total RNA was extracted by the NucleoSpin ${ }^{\circledR}$ RNA Plus Kit (Macherey-Nagel, Germany) according to the appropriate protocol. The cDNA synthesis was prepared using oligoT primers and SuperScript II transcriptase (Invitrogen/Life Technologies, USA). The cDNA of CML leukemic cell lines and control cell lines was used during the development. The PCR reaction medium consisted of $2 \mu \mathrm{l}$ cDNA, $10 \mu 1$ 2x gb SG PCR Master Mix (Generi Biotech), $1 \mu \mathrm{l}$ of each primer $(5 \mu \mathrm{M})$, in a final volume of $20 \mu \mathrm{l}$. PCR was performed using a CFX96 Touch Real-Time PCR Detection Systems (Bio-Rad).

$a 2 b 2$ (e13b2) and a2b3 (e14b2) transcript variants

For this purpose, the sequences of primers used for RT PCR were as follows:

\section{a2b2 (310 bp) BCR-b2 5'- ACAGAATTCCGCTGACCATCAATAAG-3'}


bioRxiv preprint doi: https://doi org/101101/2021.06 28 450156; this version posted June 28, 2021. The copyright holder for this preprint (which was not certified by peer review) is the author/funder, who has granted bioRxiv a license to display the preprint in perpetuity. It is made available under aCC-BY-NC-ND 4.0 International license.

a2b3 (385 bp) BCR-b2 5'- ACAGAATTCCGCTGACCATCAATAAG-3'

ABL-a2 5'- TGTTGACTGGCGTGATGTAGTTGCTTGG-3'

Amplification was performed under the following cycling conditions: initial denaturation at $95{ }^{\circ} \mathrm{C}$ for 2 minutes, followed by 40 cycles at $95{ }^{\circ} \mathrm{C}$ for 1 minute, $60^{\circ} \mathrm{C}$ for 1 minute, and $72{ }^{\circ} \mathrm{C}$ for 30 seconds, followed by a final 10-minute extension step at $72^{\circ} \mathrm{C}$. A successful reaction was verified by agarose gel electrophoresis.

\section{Nested PCR}

Long-range nested RT-PCR analysis was performed to amplify $B C R-A B L \mathrm{cDNA}$. For this purpose the sequences of primers used for RT PCR were as follows:

Step 1: $\quad$ BCR1-F 5'- TGACCAACTCGTGTGTGAAACTC-3'

ABL1-R 5'-TCCACTTCGTCTGAGATACTGGATT-3'

Step 2:

\section{ABL1-F 5'-CGCAACAAGCCCACTGTCT -3'}

\section{ABL1-R 5'-TCCACTTCGTCTGAGATACTGGATT-3'}

Step 1 conditions: initial denaturation at $95{ }^{\circ} \mathrm{C}$ for 2 minutes, followed by 40 cycles at $95{ }^{\circ} \mathrm{C}$ for 1 minute, $60{ }^{\circ} \mathrm{C}$ for 1 minute, and $72{ }^{\circ} \mathrm{C}$ for 3 minutes, followed by a final 10 -minute extension step at $72{ }^{\circ} \mathrm{C}$. The reaction was verified by $2 \%$ agarose gel electrophoresis.

Step 2 conditions: initial denaturation at $95{ }^{\circ} \mathrm{C}$ for 2 minutes, followed by 50 cycles at $95{ }^{\circ} \mathrm{C}$ for 1 minute, $60{ }^{\circ} \mathrm{C}$ for 1 minute, and $72{ }^{\circ} \mathrm{C}$ for 3 minutes, followed by a final 10 -minute extension step at $72{ }^{\circ} \mathrm{C}$. The reaction was verified by $2 \%$ agarose gel electrophoresis.

\section{Mutation Analysis of the BCR-ABL Kinase Domain}

Sequencing

PCR products were separated on 2\% agarose gel containing MIDORIGreen Advance. Appropriate bands were cut out and purified with the QIAquick Gel Extraction kit (Qiagen). Sanger sequencing was performed on ABI PRISM 3500 Genetic Analyzer using Big Dye Terminator 3.1 kit (Applied Biosystems). The resulting sequences were analyzed in Chromas 2.31 program and tools/program of Blast was used for alignment of sequences.

Cytogenetic analyses

Cells were treated with demecolcin for 1,5 hours. Harvesting and preparation of slides were performed 
bioRxiv preprint doi: https://doi org/10.1101/2021.06.28.450156; this version posted June 28,2021 . The copyright holder for this preprint (which was not certified by peer review) is the author/funder, who has granted bioRxiv a license to display the preprint in perpetuity. It is made available under aCC-BY-NC-ND 4.0 International license.

according to standard cytogenetic procedures. Cells were stored at $-20^{\circ} \mathrm{C}$ in methanol-glacial acetic acid (3:1). For cytogenetic analyses, cell suspensions were dropped on microscopic slides and air-dried. Fluorescence in situ hybridization (FISH) in combination with multicolor fluorescence in situ hybridization (mFISH) were used to characterize the chromosomes. Analyses were performed using commercially available probes BCR/ABL Vysis LSI BCR/ABL Dual Color, Dual Fusion Translocation Probe (Abbott Vysis, USA), and 24 XCyte mFISH Kit (MetaSystems, Germany). All available mitoses for both probes and two hundred nuclei for the LSI BCR/ABL probe were analyzed using an AxioImager Z1 fluorescence microscope (Carl Zeiss, Germany) and the Isis computer analysis system (MetaSystems, Germany). Findings were described according to ISCN 2016 71.

\section{Phosphorylation antibody microarray}

The Phospho Explorer Antibody Array PEX100 containing 1,318 well-characterized site-specific antibodies was purchased from Full Moon Biosystems (Sunnyvale, CA, USA). The isolated whole fraction of leukocytes was lysed in the appropriate cell lysis buffer and applied to the microarray according to the manufacturer's instructions. Briefly, lysed cells were labeled by Biotin, placed to glass array, and incubated overnight at $4{ }^{\circ} \mathrm{C}$. Cy3-Streptavidin was used for protein visualization, signal to noise ratio was measured on GenePix ${ }^{\circledR}$ Microarray Scanner (4000A; Molecular Devices, USA).

\section{$\underline{\text { Statistics }}$}

Statistical analysis was performed using GraphPad Prism 8.2 software (GraphPad Software, Inc.). Analyses were assessed by repeated-measures ANOVA, Dunnett's multiple comparisons test was used. Statistically significant results were obtained in independent biological replicates. $\mathrm{P}<0.05$ was considered statistically significant. Experiments were repeated at least three times. All data are presented as the mean \pm standard deviation.

\section{Abbreviations:}

Casein kinase 2 (CK2), tyrosine kinase inhibitors (TKIs),

Conflict of interest: The authors declare no relevant conflict of interest.

Funding: Research was supported by the Ministry of Health, Czech Republic, (project for conceptual development of research organization No 00023736). 
bioRxiv preprint doi: https://doi org/10.1101/2021.06.28 450156; this version posted June 28 2021. The copyright holder for this preprint (which was not certified by peer review) is the author/funder, who has granted bioRxiv a license to display the preprint in perpetuity. It is made available under aCC-BY-NC-ND 4.0 International license.

\section{Reference:}

1. Rowley, J. D. NEW CONSISTENT CHROMOSOMAL ABNORMALITY IN CHRONIC MYELOGENOUS LEUKEMIA IDENTIFIED BY QUINACRINE FLUORESCENCE AND GIEMSA STAINING. Nature 243, 290-293 ST-NEW CONSISTENT CHROMOSOMAL ABNORMALI (1973).

2. Zubay, G. et al. Efficacy and safety of a specific inhibitor of the BCR-ABL tyrosine kinase in chronic myeloid leukemia: Activity of a specific inhibitor of the BCR-ABL tyrosine kinase in the blast crisis of chronic myeloid leukemia and acute lympoblastic leukemia with th. Chemtracts 14, 733-738 (2001).

3. Kantarjian, H. et al. Hematologic and cytogenetic responses to imatinib mesylate in chronic myelogenous leukemia. N. Engl. J. Med. 346, 645-652 ST-Hematologic and cytogenetic response (2002).

4. Druker, B. J. et al. Efficacy and Safety of a Specific Inhibitor of the BCR-ABL Tyrosine Kinase in Chronic Myeloid Leukemia. N. Engl. J. Med. 344, 1031-1037 (2001).

5. Özgür Yurttaş, N. \& Eşkazan, A. E. Novel therapeutic approaches in chronic myeloid leukemia. Leukemia Research 91, 106337 (2020).

6. Hochhaus, A. et al. Expert opinion-management of chronic myeloid leukemia after resistance to second-generation tyrosine kinase inhibitors. Leukemia 34, 1495-1502 (2020).

7. García-Gutiérrez, V. \& Hernández-Boluda, J. C. Current Treatment Options for Chronic Myeloid Leukemia Patients Failing Second-Generation Tyrosine Kinase Inhibitors. J. Clin. Med. 9, 2251 (2020).

8. Milojkovic, D. et al. Responses to second-line tyrosine kinase inhibitors are durable: An intention-totreat analysis in chronic myeloid leukemia patients. Blood 119, 1838-1843 (2012).

9. Grant, S. Recruiting TP53 to target chronic myeloid leukemia stem cells. Haematologica 105, 11721174 (2020).

10. Némethová, V. \& Rázga, F. Chronic myelogenous leukemia on target. Cancer Med. 7, 3406-3410 (2018)

11. Pietarinen, P. O. et al. Novel drug candidates for blast phase chronic myeloid leukemia from high- 
bioRxiv preprint doi: https://doi org/10.1101/2021.06 28,450156; this version posted June 28,2021 . The copyright holder for this preprint (which was not certified by peer review) is the author/funder, who has granted bioRxiv a license to display the preprint in perpetuity. It is made available under aCC-BY-NC-ND 4.0 International license.

throughput drug sensitivity and resistance testing. Blood Cancer J. 5, e309 (2015).

12. Morotti, A. et al. Protein Kinase CK2: A Targetable BCR-ABL Partner in Philadelphia Positive Leukemias. Adv. Hematol. 2015, 612567 (2015).

13. Salvi, M., Sarno, S., Cesaro, L., Nakamura, H. \& Pinna, L. A. Extraordinary pleiotropy of protein kinase CK2 revealed by weblogo phosphoproteome analysis. Biochim. Biophys. Acta - Mol. Cell Res. 1793, 847-859 (2009).

14. Ahmed, K., Gerber, D. A. \& Cochet, C. Joining the cell survival squad: An emerging role for protein kinase CK2. Trends in Cell Biology 12, 226-230 (2002).

15. Litchfield, D. W. Protein kinase CK2 : structure, regulation and role in cellular decisions of life and death. Biochem. J 369, (2003).

16. Ahmad, K. A., Wang, G., Unger, G., Slaton, J. \& Ahmed, K. Protein kinase CK2 - A key suppressor of apoptosis. Adv. Enzyme Regul. 48, 179-187 (2008).

17. St-Denis, N. A. \& Litchfield, D. W. From birth to death: The role of protein kinase CK2 in the regulation of cell proliferation and survival. Cellular and Molecular Life Sciences 66, 1817-1829 (2009).

18. Borgo, C. \& Ruzzene, M. Role of protein kinase CK2 in antitumor drug resistance. J. Exp. Clin. Cancer Res. 38, 287 (2019).

19. Franchin, C. et al. Exploring the CK2 paradox: Restless, dangerous, dispensable. Pharmaceuticals 10, $11(2017)$

20. Duncan, J. S. \& Litchfield, D. W. Too much of a good thing: The role of protein kinase CK2 in tumorigenesis and prospects for therapeutic inhibition of CK2. Biochimica et Biophysica Acta - Proteins and Proteomics 1784, 33-47 (2008).

21. Dominguez, I., Sonenshein, G. E. \& Seldin, D. C. CK2 and its role in Wnt and NF-кB signaling: Linking development and cancer. Cellular and Molecular Life Sciences 66, 1850-1857 (2009).

22. Ruzzene, M. \& Pinna, L. A. Addiction to protein kinase CK2: A common denominator of diverse cancer 
bioRxiv preprint doi: https://doi org/10.1101/2021.06.28 450156; this version posted June 28,2021 . The copyright holder for this preprint (which was not certified by peer review) is the author/funder, who has granted bioRxiv a license to display the preprint in perpetuity. It is made available under aCC-BY-NC-ND 4.0 International license.

cells? Biochim. Biophys. Acta - Proteins Proteomics 1804, 499-504 (2010).

23. Glavy, J. S., Horwitz, S. B. \& Orr, G. A. Identification of the in vivo phosphorylation sites for acidicdirected kinases in murine mdr1b P-glycoprotein. J. Biol. Chem. 272, 5909-5914 (1997).

24. Stolarczyk, E. I. et al. Casein kinase $2 \alpha$ regulates multidrug resistance-associated protein 1 function via phosphorylation of Thr249. Mol. Pharmacol. 82, 488-499 (2012).

25. Di Maira, G. et al. Pharmacological inhibition of protein kinase CK2 reverts the multidrug resistance phenotype of a CEM cell line characterized by high CK2 level. Oncogene 26, 6915-6926 (2007).

26. Siddiqui-Jain, A. et al. The discovery and characterization of CX-5011, a highly selective, potent inhibitor of Protein Kinase CK2. Cancer Res. 68, (2008).

27. Chua, M. M. J. et al. CK2 in cancer: Cellular and biochemical mechanisms and potential therapeutic target. Pharmaceuticals 10, 18 (2017).

28. D’amore, C., Borgo, C., Sarno, S. \& Salvi, M. Role of CK2 inhibitor CX-4945 in anti-cancer combination therapy - potential clinical relevance. doi:10.1007/s13402-020-00566-w

29. Hochhaus, A. et al. European LeukemiaNet 2020 recommendations for treating chronic myeloid leukemia. Leukemia 34, 966-984 (2020).

30. Lees-Miller, S. P. \& Anderson, C. W. Two human 90-kDa heat shock proteins are phosphorylated in vivo at conserved serines that are phosphorylated in vitro by casein kinase II. J. Biol. Chem. 264, 24312437 (1989).

31. Mollapour, M. \& Neckers, L. Post-translational modifications of Hsp90 and their contributions to chaperone regulation. Biochimica et Biophysica Acta - Molecular Cell Research 1823, 648-655 (2012).

32. Zanin, S. et al. Effects of the CK2 Inhibitors CX-4945 and CX-5011 on Drug-Resistant Cells. PLoS One 7, e49193 (2012).

33. Borgo, C. et al. Aberrant signalling by protein kinase CK2 in imatinib-resistant chronic myeloid leukaemia cells: Biochemical evidence and therapeutic perspectives. Mol. Oncol. 7, 1103-1115 (2013). 
bioRxiv preprint doi: https://doi org/10.1101/2021.06.28 450156; this version posted June 28 2021. The copyright holder for this preprint (which was not certified by peer review) is the author/funder, who has granted bioRxiv a license to display the preprint in perpetuity. It is made available under aCC-BY-NC-ND 4.0 International license.

34. Salizzato, V., Borgo, C., Cesaro, L., Pinna, L. A. \& Donella-Deana, A. Inhibition of protein kinase CK2 by CX-5011 counteracts imatinib-resistance preventing rpS6 phosphorylation in chronic myeloid leukaemia cells: new combined therapeutic strategies. Oncotarget 7, 18204-18218 (2016).

35. Gribble, S. M. et al. Cytogenetics of the chronic myeloid leukemia-derived cell line K562 karyotype clarification by multicolor fluorescence in situ hybridization, comparative genomic hybridization, and locus-specific fluorescence in situ hybridization. Cancer Genet. Cytogenet. 118, 1-8 (2000).

36. Naumann, S., Reutzel, D., Speicher, M. \& Decker, H. J. Complete karyotype characterization of the K562 cell line by combined application of G-banding, multiplex-fluorescence in situ hybridization, fluorescence in situ hybridization, and comparative genomic hybridization. Leuk. Res. 25, 313-322 (2001).

37. Intemann, J., Saidu, N. E. B., Schwind, L. \& Montenarh, M. ER stress signaling in ARPE-19 cells after inhibition of protein kinase CK2 by CX-4945. Cell. Signal. 26, 1567-1575 (2014).

38. Jung, J. Il, Park, K. Y., Kim, S. A. \& Kim, J. Synergistic therapeutic effect of diethylstilbestrol and CX4945 in human acute T-lymphocytic leukemia cells. Biomed. Pharmacother. 98, 357-363 (2018).

39. Hériché, J. K. \& Chambaz, E. M. Protein kinase CK2alpha is a target for the Abl and Bcr-Abl tyrosine kinases. Oncogene 17, 13-8 (1998).

40. Mishra, S. et al. Protein kinase CKIIalpha interacts with the Bcr moiety of Bcr/Abl and mediates proliferation of Bcr/Abl-expressing cells. Oncogene 22, 8255-62 (2003).

41. Borgo, C. et al. CK2 modulates adipocyte insulin-signaling and is up-regulated in human obesity. Sci. Rep. 7, 1-15 (2017).

42. D'Amore, C. et al. A Journey through the Cytoskeleton with Protein Kinase CK2. Curr. Protein Pept. Sci. 20, 547-562 (2019).

43. Lettieri, A. et al. Protein kinase CK2 subunits differentially perturb the adhesion and migration of GN11 cells: A model of immature migrating neurons. Int. J. Mol. Sci. 20, 5951 (2019).

44. Litchfield, D. W. Protein kinase CK2: Structure, regulation and role in cellular decisions of life and 
bioRxiv preprint doi: https://doi org/10.1101/2021.06.28 450156; this version posted June 28,2021 . The copyright holder for this preprint (which was not certified by peer review) is the author/funder, who has granted bioRxiv a license to display the preprint in perpetuity. It is made available under aCC-BY-NC-ND 4.0 International license.

death. Biochemical Journal 369, 1-15 (2003).

45. Ruzzene, M. \& Pinna, L. A. Addiction to protein kinase CK2: A common denominator of diverse cancer cells? Biochim. Biophys. Acta - Proteins Proteomics 1804, 499-504 (2010).

46. Jin, S. K. et al. Protein kinase CK2 $\alpha$ as an unfavorable prognostic marker and novel therapeutic target in acute myeloid leukemia. Clin. Cancer Res. 13, 1019-1028 (2007).

47. Mishra, S. et al. Treatment of P190 Bcr/Abl lymphoblastic leukemia cells with inhibitors of the serine/threonine kinase CK2 [4]. Leukemia 21, 178-180 (2007).

48. Silva, A. et al. PTEN posttranslational inactivation and hyperactivation of the PI3K/Akt pathway sustain primary T cell leukemia viability. J. Clin. Invest. 118, 3762-74 (2008).

49. Salizzato, V., Borgo, C., Cesaro, L., Pinna, L. A. \& Donella-Deana, A. Inhibition of protein kinase CK2 by CX-5011 counteracts imatinib-resistance preventing rpS6 phosphorylation in chronic myeloid leukaemia cells: New combined therapeutic strategies. Oncotarget 7, 18204-18218 (2016).

50. Morotti, A. et al. Protein Kinase CK2: A Targetable BCR-ABL Partner in Philadelphia Positive Leukemias. Advances in Hematology 2015, (2015).

51. Ž́áčková, M. et al. Hsp90 - a potential prognostic marker in CML. Blood Cells, Mol. Dis. 50, 184-189 (2013).

52. Bachman, A. B. et al. Phosphorylation induced cochaperone unfolding promotes kinase recruitment and client class-specific Hsp90 phosphorylation. Nat. Commun. 9, 1-14 (2018).

53. Prodromou, C. Mechanisms of Hsp90 regulation. Biochemical Journal 473, 2439-2452 (2016).

54. Miyata, Y. \& Nishida, E. CK2 binds, phosphorylates, and regulates its pivotal substrate Cdc37, an Hsp90-cochaperone. Mol. Cell. Biochem. 274, 171-179 (2005).

55. Illmer, T. et al. P-glycoprotein-mediated drug efflux is a resistance mechanism of chronic myelogenous leukemia cells to treatment with imatinib mesylate. Leukemia 18, 401-408 (2004).

56. Peng, X. X., Tiwari, A. K., Wu, H. C. \& Chen, Z. S. Overexpression of P-glycoprotein induces acquired 
bioRxiv preprint doi: https://doi org/10.1101/2021.06.28 450156; this version posted June 28 2021. The copyright holder for this preprint (which was not certified by peer review) is the author/funder, who has granted bioRxiv a license to display the preprint in perpetuity. It is made available under aCC-BY-NC-ND 4.0 International license.

resistance to imatinib in chronic myelogenous leukemia cells. Chin. J. Cancer 31, 110-118 (2012).

57. Kurokawa, M., Zhao, C., Reya, T. \& Kornbluth, S. Inhibition of Apoptosome Formation by Suppression of Hsp90 Phosphorylation in Tyrosine Kinase-Induced Leukemias. Mol. Cell. Biol. 28, 5494-5506 (2008).

58. Soverini, S. et al. Implications of BCR-ABL1 kinase domain-mediated resistance in chronic myeloid leukemia. Leukemia Research 38, 10-20 (2014).

59. HRDINOVA, T. et al. Exosomes released by imatinib-resistant K562 cells contain specific membrane markers, IFITM3, CD146 and CD36 and increase the survival of imatinib-sensitive cells in the presence of imatinib. Int. J. Oncol. 58, 238-250 (2021).

60. Noel, B. M. et al. Multiomic Profiling of Tyrosine Kinase Inhibitor-Resistant K562 Cells Suggests Metabolic Reprogramming to Promote Cell Survival. J. Proteome Res. 18, 1842-1856 (2019).

61. Cortes, J. \& Lang, F. Third-line therapy for chronic myeloid leukemia: current status and future directions. Journal of Hematology and Oncology 14, 44 (2021).

62. Donato, N. J. et al. BCR-ABL independence and LYN kinase overexpression in chronic myelogenous leukemia cells selected for resistance to STI571. Blood 101, 690-698 ST-BCR-ABL independence and LYN kinase (2003).

63. Obr, A., Röselová, P., Grebeňová, D. \& Kuželová, K. Real-time analysis of imatinib- and dasatinibinduced effects on chronic myeloid leukemia cell interaction with fibronectin. PLoS One 9, (2014).

64. Yokoyama, T., Kamata, Y. \& Ohtsuki, K. Casein kinase 2 (CK2)-mediated reduction of the activities of Src family tyrosine kinases in vitro. Biol. Pharm. Bull. 27, 1895-1899 (2004).

65. Donella-Deana, A. et al. Tyrosine phosphorylation of protein kinase CK2 by Src-related tyrosine kinases correlates with increased catalytic activity. Biochem. J. 372, 841-849 (2003).

66. Faber, E. et al. Major molecular response achieved with dasatinib in a CML patient with F317L BCRABL kinase domain mutation. Leukemia Research 34, (2010).

67. White, D. et al. In vitro sensitivity to imatinib-induced inhibition of ABL kinase activity is predictive of 
bioRxiv preprint doi: https://doi.org/10.1101/2021.06 28.450156; this version posted June 28,2021 . The copyright holder for this preprint

(which was not certified by peer review) is the author/funder, who has granted bioRxiv a license to display the preprint in perpetuity. It is made available under aCC-BY-NC-ND 4.0 International license.

molecular response in patients with de novo CML. Blood 106, 2520-2526 (2005).

68. Žáčková, M. et al. Simplifying procedure for prediction of resistance risk in CML patients - Test of sensitivity to TKI ex vivo. Blood Cells, Mol. Dis. 58, 67-75 (2016).

69. Manni, S. et al. Protein Kinase CK2 Inhibition Down Modulates the NF-кB and STAT3 Survival Pathways, Enhances the Cellular Proteotoxic Stress and Synergistically Boosts the Cytotoxic Effect of Bortezomib on Multiple Myeloma and Mantle Cell Lymphoma Cells. PLoS One 8, e75280 (2013).

70. Mahon, F. X. et al. Selection and characterization of BCR-ABL positive cell lines with differential sensitivity to the tyrosine kinase inhibitor STI571: diverse mechanisms of resistance. Blood $\mathbf{9 6 , 1 0 7 0}$ 1079 (2000).

71. McGowan-Jordan, J. ISCN 2016: An International System for Human Cytogenomic Nomenclature (2016); Recommendations of the International Standing Human Committee on Human Cytogenomic Nomenclature Including New Sequence-based Cytogenomic. (Karger, 2016). 